\title{
Provenance of heavy minerals to the Middle and Upper Jurassic epicontinental deposits of NW Poland
}

\author{
Kinga BEMBENEK ${ }^{1}$, Barbara WORONKO ${ }^{1, *}$ and Piotr ZIÓŁKOWSKI ${ }^{1}$ \\ 1 University of Warsaw, Faculty of Geology, Żwirki i Wigury 93, 02-089 Warszawa, Poland
}

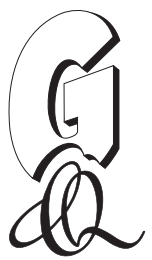

Bembenek, K., Woronko, B., Ziółkowski, P., 2021. Provenance of heavy minerals to the Middle and Upper Jurassic epicontinental deposits of NW Poland. Geological Quarterly, 65: 2, doi: 10.7306/gq.1573

\begin{abstract}
The source of clastic material supplied to the epicontinental sea during the Middle and Late Jurassic in the Pomeranian Segment of the northern part of the Mid-Polish Trough is analysed, using deposits from the Rzeczyn PIG-1 borehole that represent the Łyna, Chociwel, Brda, Pałuki, Kcynia and Rogoźno formations. Heavy mineral analysis, including weathering indices (ZTR, GZI, RZI and Q) and standardised scores for each mineral species, shows that each formation is characterized by a different heavy minerals association. In each association, transparent minerals include both ultrastable minerals (zircon, tourmaline and rutile), occurring in various proportions, and unstable minerals. This indicates that deposits subject to earlier multiple reworking were eroded from the surrounding landmasses. Most probably these deposits represented Triassic rocks, although fresh weathering covers were also eroded. The main direction of clastic material supply was from the $\mathrm{N}$ and NW, and to a lesser degree from the NE. The main reasons for changes in the source areas were probably sea level oscillations, while during regressions, exposed parts of the seabed became source areas of clastic material. Conversely, during transgressions, parts of the seabed became cut off from the supply of clastic material from eroded landmasses.
\end{abstract}

Key words: Middle and Upper Jurassic, weathering indices, sea level change, stratigraphic gaps.

\section{INTRODUCTION}

The Mid-Polish Trough (MPT), being the continuation of the Danish-Polish Basin, comprises the easternmost branch of the Central European Basin System (CEBS) (Michelsen, 1997; Ziegler, 1990; van Wees et al., 2000; Krzywiec, 2002; Dadlez, 2003). The MPT was the deepest (10 km thick) and the largest (700 km long and up to $100 \mathrm{~km}$ wide) epicontinental basin system of the West- and Central-European Plates (Ziegler, 1990; Dadlez, 2003). The MPT extended along the TeisseyreTornquist Zone (TTZ), from the West Pomerania region in the north-west to the Holy Cross Mountains area in the south-east and, in the Late Jurassic, also to western Ukraine. It remained there for 150 million years until its inversion into the Mid-Polish Swell in the latest Cretaceous and the beginning of the Paleogene (Ziegler, 1990; Dadlez, 2003). The Mid-Polish Trough generally runs along the TTZ and the Trans-European Suture Zone (TESZ), which shows that a particular crustal rheology contrast (including a weakness zone) played a significant role in its development (Poprawa, 1997; Królikowski et al., 1999). The thick of Mesozoic deposits that accumulated in the MPT are a source of information on climate and sea level changes, sedimentary provenance, and palaeogeography

\footnotetext{
* Corresponding author, e-mail: bworonko@uw.edu.pl
}

Received: June 17, 2020; accepted: October 9, 2020; first published online: January 5, 2021
(Marek and Pajchlowa, 1997; Dadlez et al., 1998; Dadlez, 2003; Krzywiec, 2006; Pieńkowski et al., 2008).

The Jurassic in Central Europe is a very diverse period in terms of palaeogeography and geotectonic domains (e.g., Pieńkowski et al., 2008; Matyja et al., 2010). Therefore, the directions of sediment supply to the MPT are difficult to reconstruct. Recognition of source areas is even more difficult when it is not clear which sediments/rocks were subject to erosion and what was the palaeogeography of the catchment area where the resulting deposits accumulated. An example of such an area is the NW part of the MPT during the Middle and Late Jurassic.

Heavy mineral analysis is one of the methods used to reconstruct sediment sources (e.g., Weltje and von Eynatten, 2004; Oszczypko and Salata, 2005; Bateman and Calt, 2007; Garzanti et al., 2007; Mange and Wright, 2007; Woronko et al., 2013; Salata and Uchman, 2013; van Loon and PisarskaJamroży, 2016; Mounteney et al., 2018). Though mainly determined by the geology of the source areas, the composition of heavy mineral associations recorded in sedimentary successions depends also on many other factors, such as: (1) intensity, duration and type of weathering that the sediments were subject to prior to erosion, (2) facies diversity of deposits in the source area, (3) different sorting processes during transport, (4) the ability of transport processes to remove material, (5) tectonic regime, (6) sea level changes, and (7) post-depositional processes. Commonly, there is a combination of several of these factors.

In 2010, the deep Rzeczyn PIG-1 borehole (Fig. 1) was drilled in NW Poland by the Polish Geological Institute - Na- 


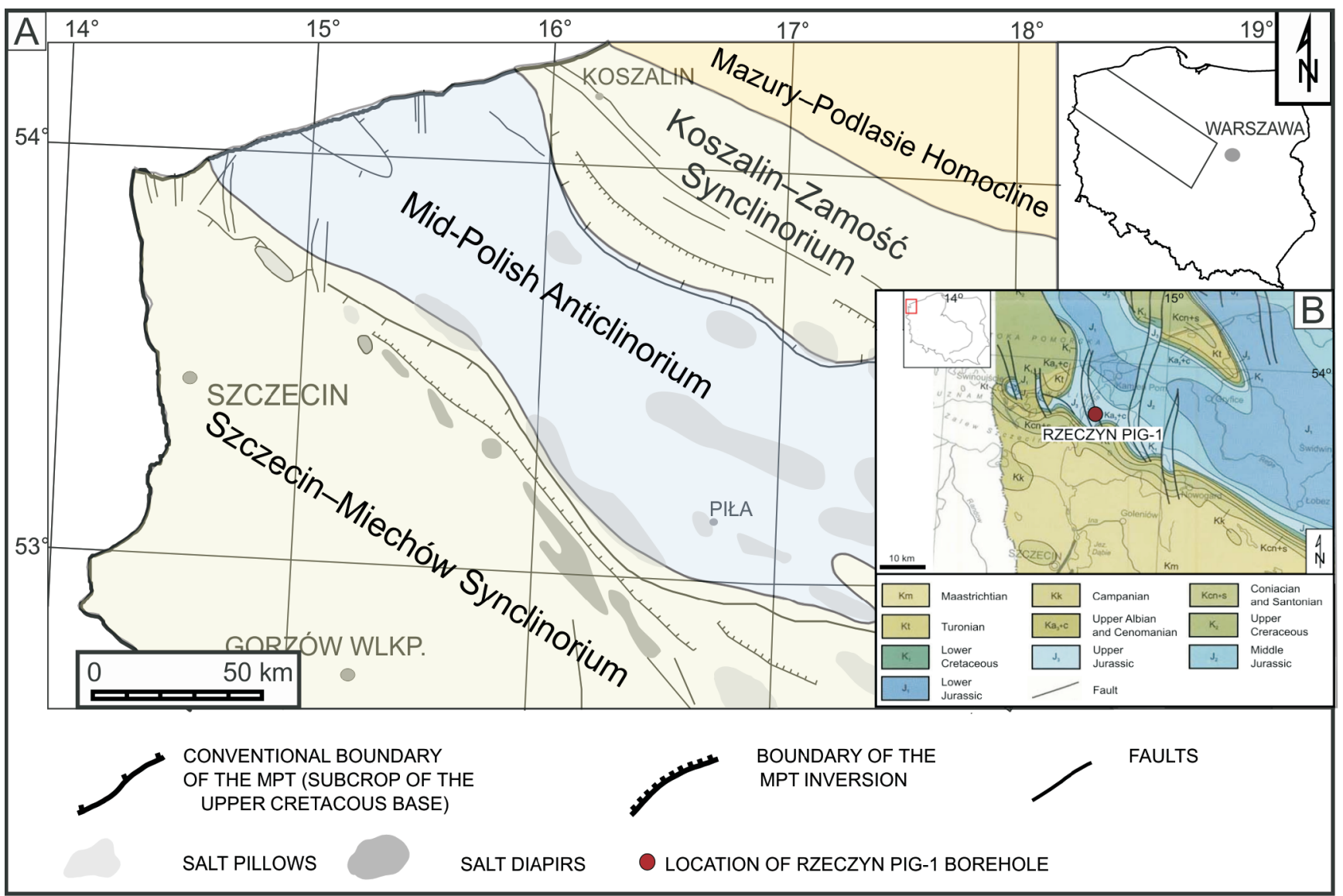

Fig. 1. Location of the Rzeczyn PIG-1 borehole (A) with respect to geological units (B) (after Dadlez et al., 2000 and Dadlez, 2003; modified)

tional Research Institute as part of the project: Integrated program of shallow research boreholes for solving crucial problems of the geological structure of Poland. Penetrating through to the Middle and Upper Jurassic boundary, this borehole is important for understanding Jurassic palaeogeography. In southern Poland and in the southern part of the European Platform, this boundary interval is marked by a stratigraphic gap and chemical weathering (Pieńkowski et al., 2008; Matyja et al., 2010).

The Rzeczyn PIG-1 core has been subject to numerous analyses, one of which was of heavy minerals. The present study was aimed at (1) explaining the variability of heavy mineral associations in these Middle and Upper Jurassic strata and (2) discussing the sediment source areas for the northern part of the Polish Basin during the Jurassic.

\section{GEOLOGICAL SETTING}

The Rzeczyn PIG-1 borehole (5351'58.64"N, $14^{\circ} 41^{\prime} 44.64^{\prime \prime E}$ ) was drilled to the NNE of Szczecin in NW Poland, in the Pomeranian Segment of the northern part of the MPT (Fig. 1; Dadlez, 2003; Żelaźniewicz et al., 2011). Extensional and compressional stages linked with the geotectonic evolution of the distant Tethyan and/or Atlantic Basin were of crucial significance in the evolution of the MPT (Dadlez, 2001; Lamarche et al., 2002; Pieńkowski et al., 2008). During the Mesozoic, the axial part of the basin was generally characterized by rapid subsidence, compaction and almost continuous sedimentation. In turn, the marginal parts of the basin were subject to erosion (Dadlez et al., 1995; Dadlez, 1997, 1998, 2000, 2001; Pieńkowski et al., 2008) and were strongly influenced by tectonic activity and sediment supply (Pieńkowski et al., 2008). According to Dadlez (1998), in the Middle Jurassic (Aalenian and Bajocian stages), the MPT became partly isolated from the basins of western Europe and opened into the Tethyan Domain. Three major phases may be distinguished in the subsidence curve for the MPT but only one phase corresponds to the Mesozoic (the Oxfordian-Kimmeridgian interval). In the NW segment of the MPT there is no evidence of major, basin-scale sediment deformation related to rapid subsidence (Dadlez, 2003; Krzywiec, 2006). The maximum thickness of Jurassic deposits is present along the MPT axis although regional fault zones and grabens existing along the edges of the MPT controlled the sedimentation style and deposit thickness (Dadlez 2001; Pieńkowski et al., 2008, 2012; Barth et al., 2018). The Polish epicontinental basin was surrounded by marginal-marine areas and lowlands. To the north it was bounded by the elevated Fennoscandian Shield, to the east by the Belarus Anteclise and the Ukrainian Shield, and to the south-west by the Bohemian Massif (Dadlez and Marek, 1997; Pieńkowski et al., 2008). Depocentre migration may be observed for the Jurassic; in the Middle Jurassic this was in the Kutno Depression, in the Late Jurassic during the Oxfordian and Early Kimmeridgian the depocentre was located on the SW margin of the SE part of the MPT, and in the Tithonian-Early Berriasian it extended to the Lviv area (western Ukraine) (Pieńkowski et al., 2008). 
LITHOLOGICAL SUCCESSION

OF THE RZECZYN PIG-1 BOREHOLE

The Rzeczyn PIG-1 borehole encompasses Quaternary $(0.00-82.95 \mathrm{~m})$, Cretaceous $(82.95-92.78 \mathrm{~m})$ and Jurassic $(92.78-236.0 \mathrm{~m})$ deposits. The borehole terminated in Middle Jurassic rocks at the depth of $236.00 \mathrm{~m}$ (Fig. 2). Based on lithological analysis coupled with biostratigraphy (ammonites and dinoflagellate cysts) and chronostratigraphy, five lithostratigraphic formations have been distinguished in the Jurassic part of the core: the Łyna, Chociwel, Brda, Pałuki, and Kcynia formations, and one in the Cretaceous - the Rogoźno Formation (Barski and Matyja, 2010; Matyja, 2010a, b; Fig. 2). Accumulation of these deposits took place on an epicontinental sea shelf (Matyja et al., 2010), on an open siliciclastic shelf, as well as on the lower and upper parts of a siliciclastic shelf and in carbonate platform settings (Ceranka et al., 2010).

The basal part of the succession between 197.86-236.00 m comprises the Łyna Formation representing the Callovian. The formation is developed as siliciclastic deposits of various grain size, from non-calcareous laminated claystones with common phytoclasts, to fine-grained sands, occasionally with bivalve detritus and millimetre-thick silt laminae. A stratigraphic gap encompassing the Koenigi-Coronatum zones was noted (Figs. 2 and 3). The formation passes continuously into the succeeding Chociwel Formation (Fig. 2). The lower part of the Łyna Formation (218.00-236.00 $\mathrm{m}$ ) accumulated on an offshore siliciclastic shelf; towards the top the deposits represent nearshore shelf $(206.45-218.00 \mathrm{~m})$ and open siliciclastic shelf settings (197.86-206.45 m; Ceranka et al., 2010).

The Chociwel Formation (depth 156.26-197.86 m) represents the Lower and Middle Oxfordian. The accumulation of these strata began with clay deposits representing an offshore siliciclastic shelf, overlain by non-calcareous clays with muscovite, cemented by calcite and intercalated with fine sand layers. Towards the top the deposit becomes more sandy. The top of the sandy deposits at the depth of $167.16 \mathrm{~m}$ is marked by an erosional boundary. A stratigraphic gap at the depth of -166.58 m encompasses part of the Lower and Middle Oxfordian, i.e. the Cordatum and Plicatilis zones (Figs. 2 and 3). Above this, there occur clays with abundant organic detritus (162.00-162.80 m). The topmost part of the Chociwel Formation is composed of sandy deposits with abundant bivalve detritus. According to Ceranka et al. (2010), the accumulation of these deposits took place on an open siliciclastic shelf. The boundary between the Chociwel Formation and the overlying Brda Formation is erosional in character (Figs. 2 and 3).

The Brda Formation (depth 140.00-156.26 m) represents carbonate deposits developed as detrital limestones with intercalations of marly limestone. Their accumulation took place on an open carbonate shelf. The top of this formation is also marked by an erosional surface (Figs. 2 and 3 ).

The Pałuki Formation occurs between 120.80-140.00 m and is represented in its lower part by micritic marly limestones with intercalations of clay, and in its upper part by marly limestones. The deposition of these strata took place on an open carbonate shelf during the Early Tithonian and/or Late Kimmeridgian (Figs. 2 and 3).

The Kcynia Formation (depth $92.78-120.80 \mathrm{~m}$ ) is a carbonate-evaporite unit representing the Lower and Upper Tithonian. It is developed mainly as micritic marly limestones with microfossils, calcareous sandstones and sandy limestones, detrital limestones and detrital marls. Subordinate facies include clays, marly claystones, fine sandstones, siltstones and marls. The top of the formation is marked by an erosional surface (Fig. 2).
The top of the succession analysed comprises non-calcareous claystones with intercalations of sandstone with a sideritic matrix and siltstone. These strata comprise the Rogoźno Formation (depth 86.00-92.78 m). Its deposition took place in the Late Berriasian (Early Cretaceous) on an open carbonate shelf (Fig. 2).

\section{MATERIAL AND METHODS}

Samples representing the Middle and Upper Jurassic and the Lower Cretaceous were collected for the heavy mineral analysis from the depth interval $82.95-235.00 \mathrm{~m}$ of the Rzeczyn PIG-1 core. A $4 \mathrm{~cm}$ thick half-core sample was collected each time. In total, 47 samples (RZ.01 - RZ.47) representing all six formations distinguished in the borehole were acquired (Fig. 2).

Most samples were characterized by a low degree of lithification, and so they were mechanically crushed in the first step. Carbonate samples were etched in $10 \%$ acetic acid $\left(\mathrm{CH}_{3} \mathrm{COOH}\right)$ and washed using hydrogen peroxide and distilled water to eliminate organic matter. Next, the $0.125-0.250 \mathrm{~mm}$ fraction was separated from each fraction. The choice of this fraction resulted from the need to optimize the heavy mineral frequency in a sample, because particular minerals attain maximum values in different size ranges, e.g. ilmenite in the $0.25-0.15 \mathrm{~mm}$ fraction, garnet in the $0.3 \mathrm{~mm}$ fraction, rutile and zircon in fraction in the $<0.06 \mathrm{~mm}$ fraction (Mycielska-Dowgiałło, 2007; Marcinkowski and Mycielska-Dowgiałło, 2013). Biotite, muscovite and chlorite were also treated as heavy minerals. The association comprising minerals occurring as single grains in a sample (chromite, epidote, hematite, sphalerite, corundum, cordierite, spinel and titanite) was distinguished as "other". Separation of heavy minerals from light minerals was made using sodium tungstate, the heavy minerals then being mounted in Canada balsam on glass slides. In some samples the number of heavy mineral grains was too low to obtain reliable results, and in some heavy minerals were absent. Therefore, only the 21 samples in which at least 70 grains of heavy minerals were present, were subject to further analysis and their indices were calculated (Fig. 2). Furthermore, to show the variability of heavy mineral composition in the succession, the analysis included 6 samples (nos. 23, 27, 28, 32, 33 and 36), in which authigenic minerals (e.g. apatite) dominate. The percentage content of all minerals analysed was counted. The sum of $100 \%$ of heavy minerals was the sum of all minerals recognized in a sample, including transparent and opaque minerals.

Mineral identification was made using a petrographic microscope and a scanning electron microscope (SEM) with EDS using unpolished heavy mineral separates. In the case of zircon and garnet grains, their roundness was determined according to the 5 point scale of Andò et al. (2012), distinguishing euhedral, angular, subrounded, rounded and broken grains.

The following provenance indices (GZI, RZI and Q), and maturity index (ZTR) were calculated based on the data obtained data:

- the ZTR index, defined by Hubert (1962) as the percentage of chemically ultrastable minerals (zircon, tourmaline, and rutile) among transparent detrital heavy minerals;

- the GZI index (garnet/zircon), calculated as the percentage contribution of garnet in total garnet plus zircon, which reflects changes in the provenance of heavy minerals (Morton and Hallsworth, 1994); 


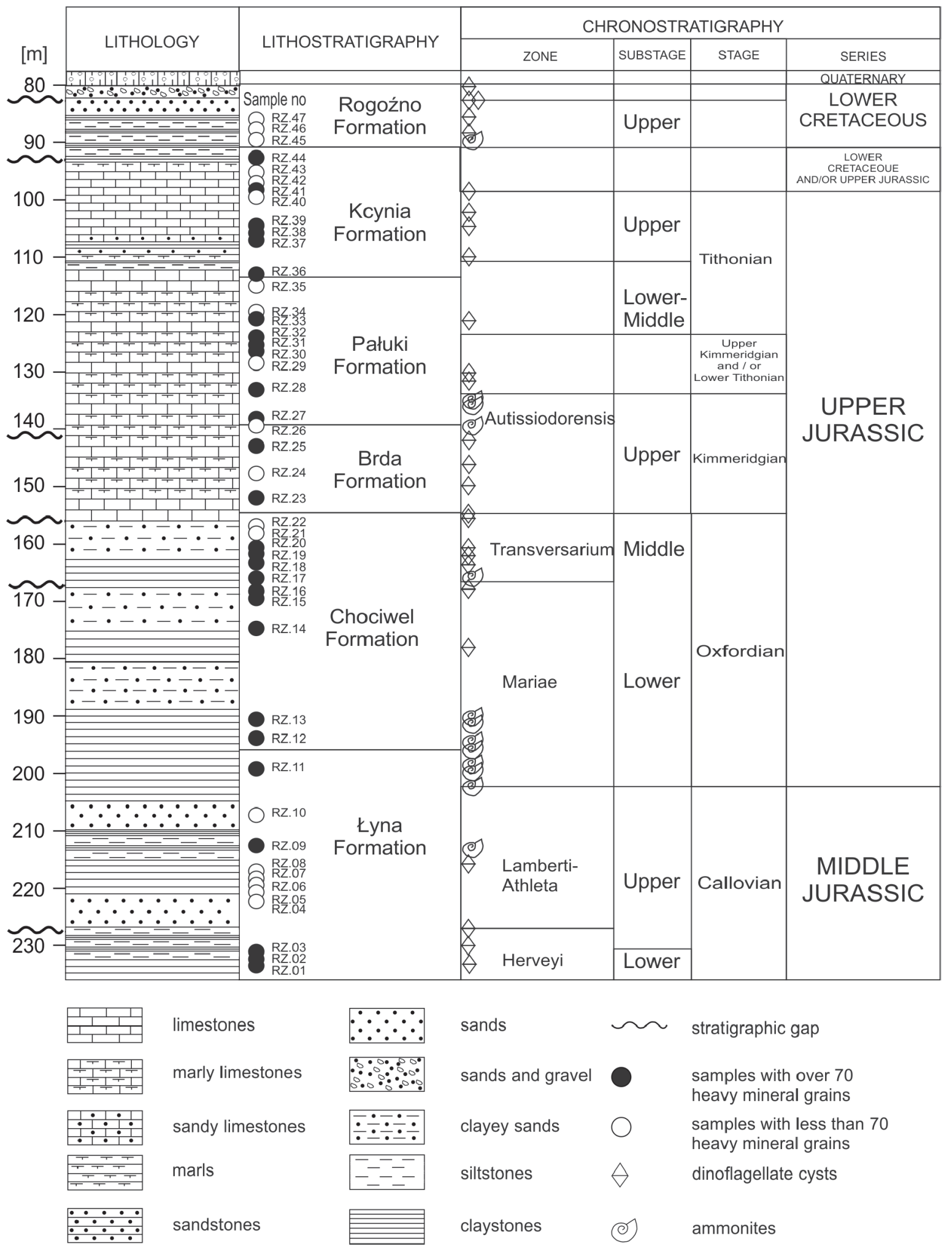

Fig. 2. Lithological column of the succession drilled in the Rzeczyn PIG-1 borehole with litho-, bioand chronostratigraphy (after Matyja et al., 2010, modified)

- the $\mathrm{TiO}_{2}$ minerals/zircon index (RZI), which corresponds mainly to variations in local diagenetic conditions related to the extent of authigenic anatase development (Morton, 2007). The index is expressed as: $100 \times\left[\mathrm{TiO}_{2}\right.$ group (anatase, brookite, rutile): $\left(\mathrm{TiO}_{2}\right.$ group + zircon)];

- the $Q$ index of Fay (1975) is expressed by the equation:

$$
Q=\frac{G+E+H}{Z r+T+R}
$$

where: the group of weathering non-resistant minerals includes garnet (G), epidote (E) and amphiboles (hornblende) (H), and the group of weathering-resistant minerals includes zircon ( $\mathrm{Zr})$, tourmaline $(\mathrm{T})$ and rutile (R). 


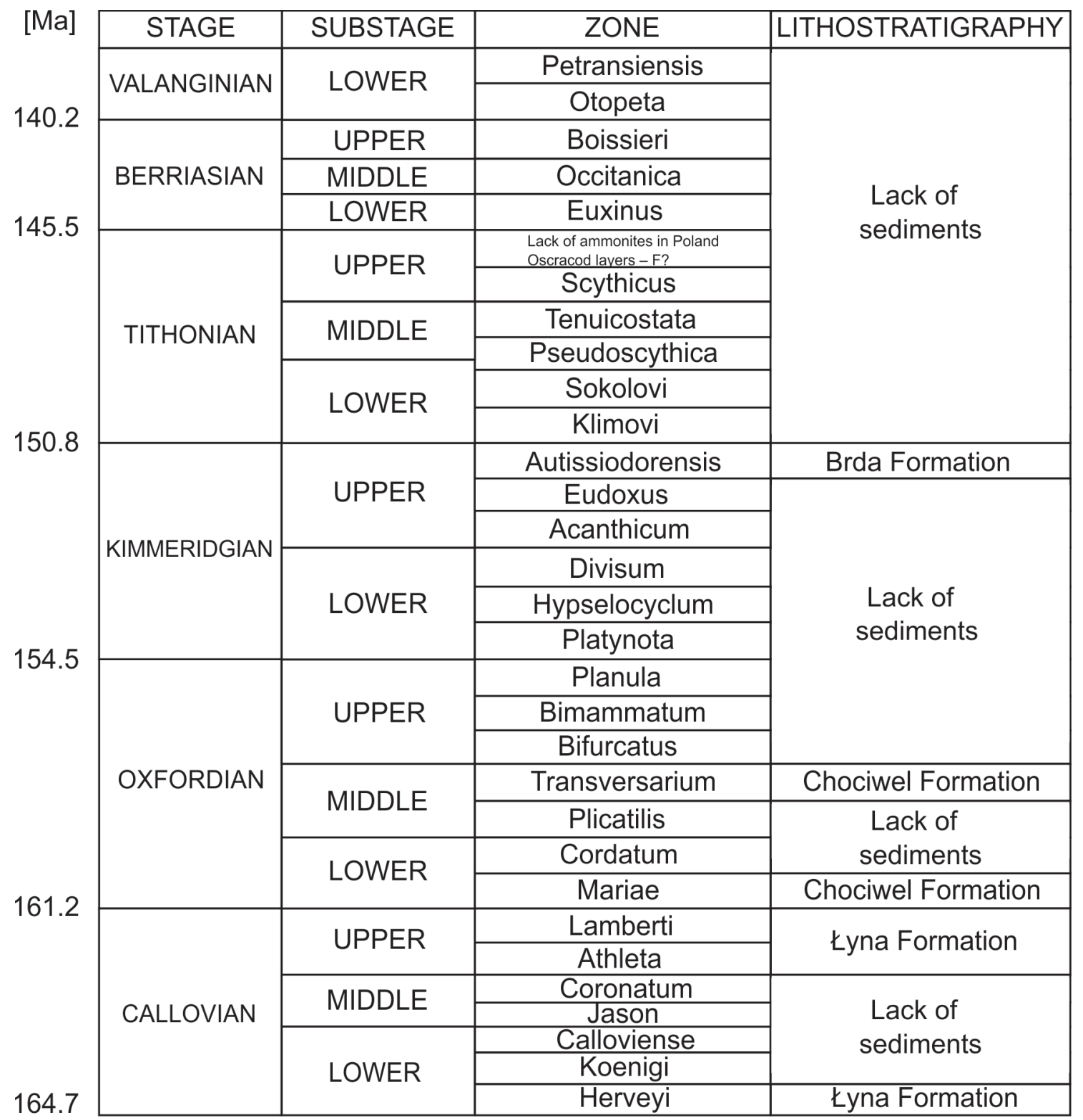

Fig. 3. Chronostratigraphy of the upper Middle and Upper Jurassic based on ammonites and dinoflagellate cysts

According to Fay (1975), this index is a good tool for showing the variability of the mineral composition that allows for the characterization of source areas. The $Q$ index has been successfully used to recognise source areas for pre-Quaternary sediments by Masłowska and Michałowska (2004).

Standardised scores were calculated for each mineral species and then plotted against stratigraphic intervals (Ryan et al., 2007). Such scores can be calculated as follows:

$$
\text { score }_{i, z}=\frac{X_{i, z}-\text { mean }_{i}}{\text { sdev }_{i}}
$$

where: $X_{i, z}$ - individual mineral count for the $i$ mineral at stratigraphic level $z$, mean $_{i}$ - mean mineral percentage for species $i$, sdev $v_{i}-$ standard deviation for species $i$.

The mean counts of each mineral, calculated separately, e.g. for zircon, in the entire succession, were used to construct the chart. Standard deviation calculated for each mineral in each sample is substituted to formula [2]. Zero in the chart re- fers to the mean score of a given mineral in the entire succession, whereas the values in the chart indicate standard deviation from the mean (Ryan et al., 2007).

\section{RESULTS}

HEAVY MINERALS COMPOSITION

MIDDLE JURASSIC

There is low abundance of heavy minerals at the base of the succession (sample RZ.01) in the clayey-sandy deposits of the Łyna Formation (Fig. 2). Transparent minerals that are relatively stable to weathering (garnet, staurolite) prevail. Their total contribution is $\sim 60 \%$ (Fig. 4). Garnet grains are poorly rounded, with subrounded grains dominating, while broken and angular grains are also present. Effects of mechanical destruction in the form of breakage, as well as of abrasion in aqueous settings, are visible on grain surfaces; effects of chemical weathering are 
poorly marked (Fig. 5). Ultrastable minerals are represented only by rutile $(17 \%)$. Unstable minerals (muscovite $-12.5 \%$ ) are also present. Ten percent of the minerals were assigned to "other" minerals. In the overlying strata (sample RZ.02), the heavy mineral association is more variable. Tourmaline, as well as subhedral and well-rounded zircon appear (Fig. 6), accompanied by amphibole and secondary apatite (Fig. 4). Samples RZ.01 and RZ.02 do not contain opaque minerals (magnetite and ilmenite), these being observed only in the top of the clayey-sandy deposits (sample RZ.03; Fig. 4). Above the stratigraphic gap (Fig. 2), minerals are represented only by authigenic pyrite in the laminated clay deposits (depth interval 217.00-228.72 m). In the sand and claystone deposits (samples RZ.09 and RZ.11), there is slight increase in the contribution of stable minerals, i.e. rutile and tourmaline, accompanied by amphibole and chlorite. Small amounts of opaque minerals were also observed (Fig. 4).

On the vertical bar chart of standardised percentage scores for individual mineral species, this unit can be distinguished by the highest contribution of garnet grains with regard to average values, being the highest at the base of the unit and diminishing upwards. Garnet is accompanied by variable contents of tourmaline, with maximum values in sample RZ.03, and low values of zircon and amphibole (Fig. 7).

The Łyna Formation is characterized by high values of the $Q$ index in its basal part (1.9 to 3.0), which diminish upwards to 0.2 . High values of the $\mathrm{GZI}$ and RZI indices are also present. In turn, values of the ZTR index display a large variability in the succession. At the base it is low (16.6), then slightly increases, to reach 73.7 at the depth of $230.80 \mathrm{~m}$ (sample RZ.03), finally decreasing to 8.9 at the top of the formation (Fig. 8).

UPPER JURASSIC

The Oxfordian section of the core (Chociwel Formation; depth $156.26-197.86 \mathrm{~m}$ ) is characterized by a large variability in heavy mineral composition. Rutile accompanied by muscovite and chlorite dominate at the base of this formation (sample RZ.12; Fig. 2), and garnet, amphibole and pyroxene grains appear above this. There is a lack of zircon and kyanite, and a low contribution of tourmaline in this part of the formation (Fig. 4). The following sample (RZ.14) yielded large amounts of ilmenite $(>71 \%)$, tourmaline, zircon, kyanite and pyroxene. IImenite still dominates above this, then its content slightly decreases. Ultrastable minerals begin to prevail (rutile, zircon, tourmaline), accompanied by staurolite and relatively stable garnet. The content of garnet slightly increases upwards (Fig. 4). Garnet grains are variously rounded, from angular to subrounded. As in deposits of the Łyna Formation, effects of mechanical destruction dominate on their surfaces (Fig. 5). In turn, zircon grains have a much better and more variable roundness than garnet grains. Sample RZ.20 contains well-rounded, subrounded and subhedral grains; broken zircon grains being also present (Fig. 6). The vertical bar chart of standardised percentage scores for individual mineral species for the heavy minerals of the Chociwel Formation demonstrates variability of tourmaline and zircon values in the formation. Moreover, the entire formation is characterized by a lower than average contribution of amphibole, garnet and rutile. The Chociwel Formation is distinguished by very low values of the $Q$ index $(0.0$ to 0.6$)$ and variable values of the remaining indices GZI, RZI and ZTR. Values of the ZTR index are very low in the lowermost part of the formation (1.5); at the depth of $170.15 \mathrm{~m}$ this index rapidly increases to over 80 , to decrease to only 13 in the upper part of the formation. At the top, the ZTR index increases again to $\sim 80$ (Fig. 8).

The overlying Upper Kimmeridgian deposits of the Brda Formation (depth 140.00-156.26 m; Fig. 2) are characterized by large amounts of authigenic apatite (54-63.8\%). Ultrastable minerals contribute to a maximum of $10.3 \%$, being represented by rutile at the base of the formation, tourmaline in the middle, and zircon and tourmaline at its top. They are accompanied by ilmenite, garnet and amphibole (Fig. 4). Garnet grains are broken, particularly among subrounded grains (Fig. 5). On the vertical bar chart of standardised percentage scores for individual mineral species, this unit is distinguished by a higher-than-average contribution of amphibole (Fig. 7). The $Q$ index in deposits of the Brda Formation varies from 0.8 to 3.5 and is higher than in the underlying Chociwel Formation. The the RZI index is 100 at the base and 0 at the top of the formation. GZI values are high, whereas ZTR values are low <20 (Fig. 8).

Authigenic apatite dominates at the base and top of the Pałuki Formation (depth 120.80-140.00 m; Fig. 2), reaching 90.74 and $81.30 \%$, respectively. Opaque minerals have not been observed in this formation. Ultrastable minerals do not occur at the base of the formation (sample RZ.28). They appear in the depth interval $128.60-128.70 \mathrm{~m}$ as zircon followed by tourmaline. Garnet was also recorded in this depth interval. Garnet and zircon grains are characterized by a similar degree of rounding as in the Brda Formation (Figs. 5 and 6). Unstable minerals are represented by amphibole, biotite and chlorite (Fig. 4). On the vertical bar chart of standardised percentage scores for individual mineral species, deposits of the Pałuki Formation are characterized by a lower than average contribution of all minerals, with the exception of sample RZ.30 (depth $128.60-128.70 \mathrm{~m}$ ), in which the contribution of amphibole is the highest, accompanied by garnet and "other" minerals (Fig. 7). The Pałuki Formation is characterized by a zero value of the RZI index, a very low value of the ZTR index and variable values of the GZI and $Q$ indexes. The latter reaches the highest value in the entire succession (4.7) at the depth of 128.60-128.70 m (sample RZ.30; Fig. 8).

The Kcynia Formation (depth 97.78-120.80 m; Fig. 2) (Tithonian) is characterized by a small contribution $(<5 \%)$ of unstable minerals (amphibole, muscovite, biotite), the only exceptions being samples RZ.38, RZ.39 and RZ.41, which contain $84.5,48.3$ and $61.3 \%$ of chlorite, respectively. Likewise, opaque minerals contribute to a low percentage among the minerals recognized, with the exception of sample RZ.44 (depth 95.1-95.73 m), where ilmenite reaches up to $50 \%$. The contribution of ultrastable minerals varies throughout the succession. At the base of the formation they contribute $3.64 \%$, increasing to $\sim 93 \%$, then decrease to $1.5 \%$, reaching from 22.1 to $44.7 \%$ at the top of the succession. This mineral group is dominated by zircon (Fig. 4). A characteristic feature of its grains is the variable degree of rounding. For example, sample RZ.37 contains well-rounded, subrounded, but also angular and euhedral grains (Fig. 6). Authigenic minerals are represented by phosphate minerals, which contribute to $89.3 \%$ of the heavy minerals at the base of the formation. At the top of the Kcynia Formation, in contrast to the underlying deposits of the Pałuki Formation, the RZI index again reaches high values from 20 to 80 . At the same time, the value of the $Q$ index is relatively high at the base and in the middle part of the formation, to fall to almost zero at its top. The ZTR index reaches its highest values at the base of the formation (up to 100), then varies from 1.5 to 60 . Each increase of the ZTR index is accompanied by a fall in the values of the remaining indices (Fig. 8). 


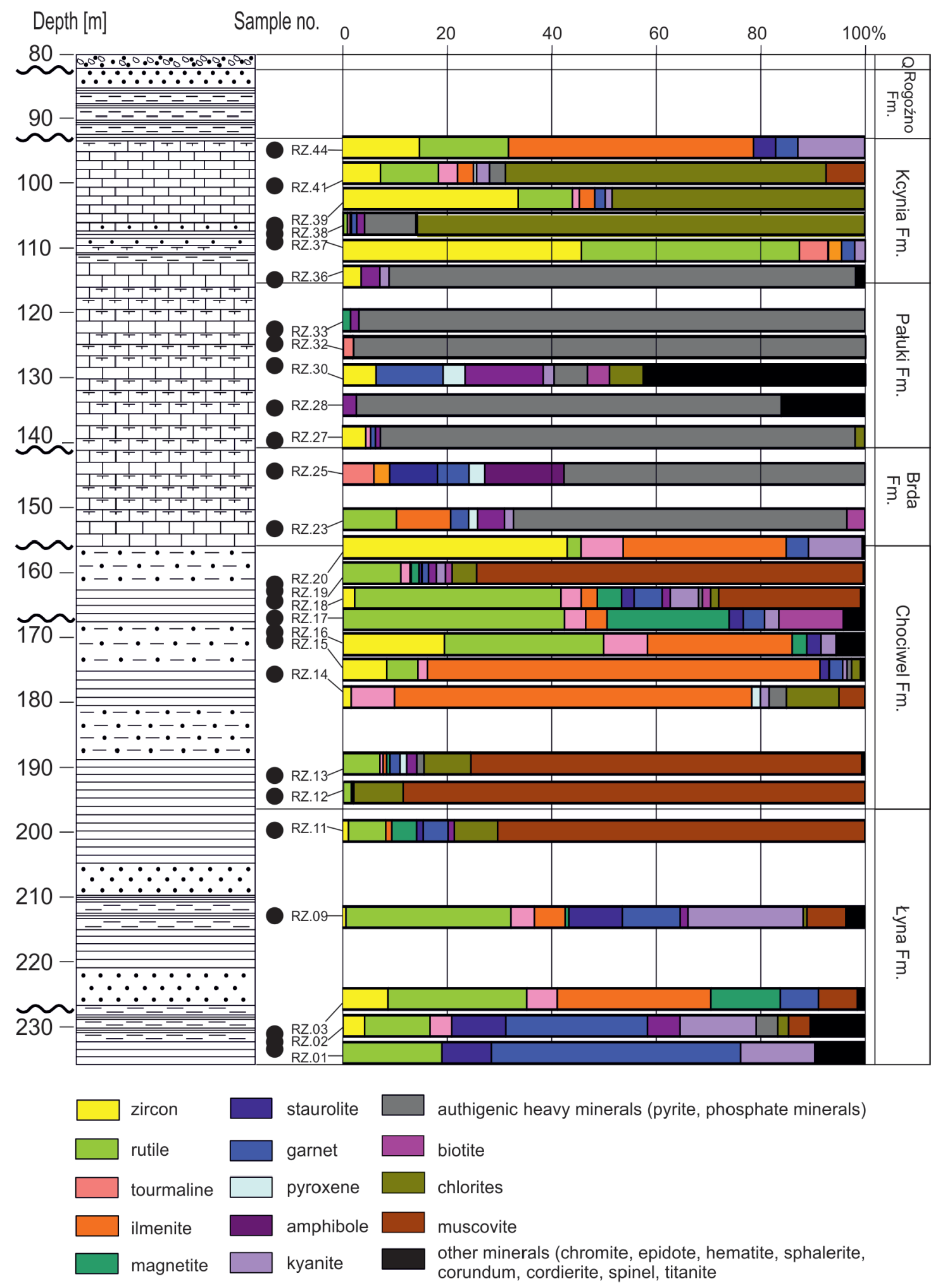

Fig. 4. Heavy mineral composition in the Middle and Upper Jurassic epicontinental deposits of the Polish Basin in the Rzeczyn PIG-1 succession

Other explanation as in Figure 2

LOWER CRETACEOUS

Samples of Lower Cretaceous deposits, represented by the Rogoźno Formation in depth interval 86.00-92.78 m (Fig. 2), did not contain any heavy minerals.

\section{DISCUSSION}

The heavy mineral associations and the values of the calculated weathering indices for the Lower and Middle Jurassic de- 


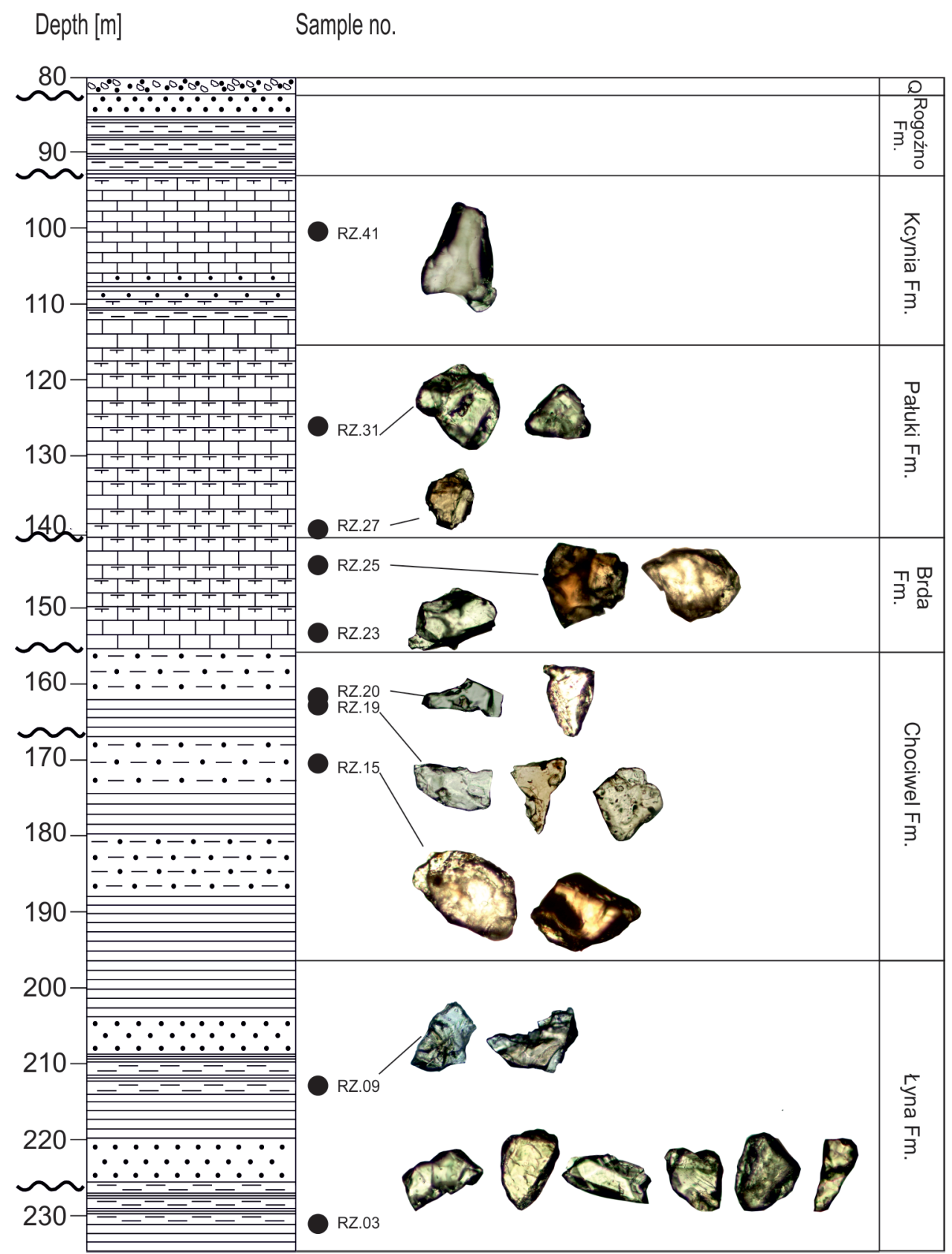

Fig. 5. Representative garnet varieties in the Kyna, Chociwel, Pałuki and Kcynia formations of the Rzeczyn PIG-1 succession

Explanations as in Figure 2

posits of the Rzeczyn PIG-1 succession are very variable. Each of the five formations (Łyna, Chociwel, Brda, Pałuki and Kcynia) is characterized by a separate heavy minerals association, consistent with the subdivision based on bio-, litho- and chronostratigraphy (Barski and Matyja, 2010, Matyja, 2010a, b; Figs. 4-8). Undoubtedly, one of the main factors responsible for this is the changing source rock area for sediments supplied to the northern part of the Polish Basin during the deposition of each formation. Sea level changes that took place in the Late Jurassic were significant in this respect also, as deduced from the stratigraphy of continental margins and basin interiors (Šimkevičius, 1998; Haq and Al-Qahtani, 2005; Pieńkowski et al., 2008; Haq, 2017), as that affects the sorting of minerals with regard to weight, shape and grain size (Cascalho and
Feradique, 2007; Komar, 2007; Woronko et al., 2013; Pisarska-Jamroży et al., 2015; Garzanti et al., 2018).

\section{HEAVY MINERAL ASSOCIATIONS IN THE RZECZYN PIG-1 SUCCESSION}

As regards the contribution of specific heavy minerals in all lithostratigraphic units of the Rzeczyn PIG-1 succession, the Łyna Formation represents a garnet-rutile-kyanite association in its basal part, and a rutile-ilmenite association higher up. The Chociwel Formation is tripartite, with rutile at its base, ilmenite in its middle part and includes a rutile-tourmaline-kyanite association in its upper part. An amphibole-ilmenite association is typical of the Brda Formation, an amphibole-zircon association is 


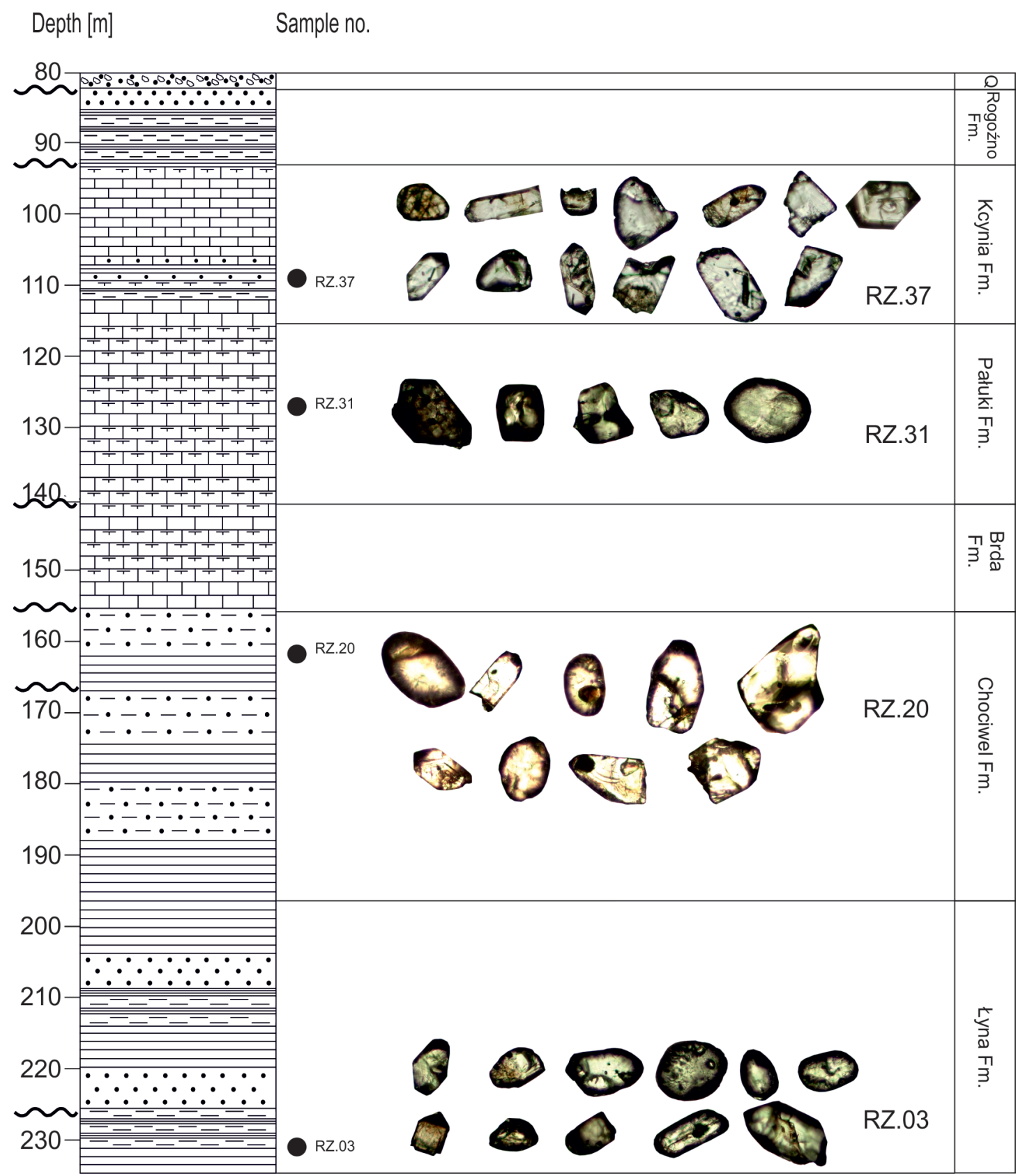

Fig. 6. Representative zircon varieties in the Łyna, Chociwel, Pałuki and Kcynia formations of the Rzeczyn PIG-1 succession

Explanations as in Figure 2

characteristic of the Pałuki Formation, and a zircon-rutile-ilmenite association occurs in the Kcynia Formation (Fig. 4).

\section{PROVENANCE OF THE DEPOSITS}

Several source areas were involved in supplying sediment to the Jurassic sea during the accumulation of each formation; however, their role was variable as shown by the changing contributions of different minerals, and the values of the provenance and maturity indices even within single units (Figs. 4, 7 and 8). The source rocks were older strata exposed to weathering, erosion and transportation, or weathered crystalline basement rocks. The Polish Basin, in this part of its history, had already filled with Lower Jurassic siliciclastic deposits in the NW part of the Mid-Polish Trough (Pożaryski and BrochwiczLewiński, 1978; Kutek et al., 1984; Dadlez et al., 1995; Kutek, 2001; Pieńkowski, 2004; Pieńkowski et al., 2008).

The palaeogeography of the Middle and Late Jurassic indicate that the sediment source areas for the formations comprising the Rzeczyn PIG-1 succession could potentially have been located in regions relatively close to the study area (Ziegler, 1978; Pieńkowski et al., 2008). The presence of both unstable minerals, such as amphibole and pyroxene, as well as ultrastable minerals, such as zircon, rutile and tourmaline in the same samples suggest that the supply of sediments to the northern part of the Jurassic basin could have taken place from different source areas. In turn, the source areas must have been built of rocks of different age, that were subject to weath- 


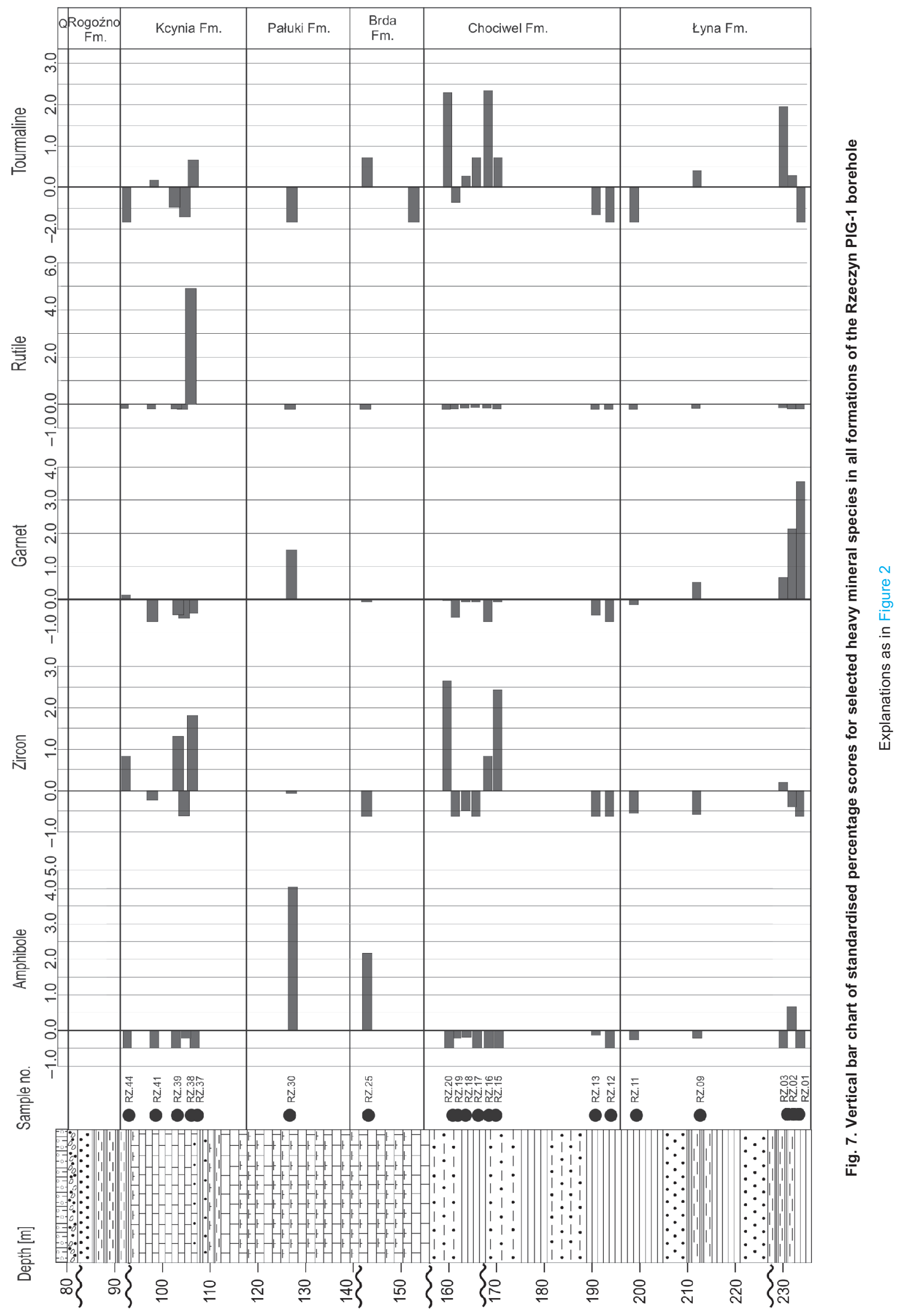




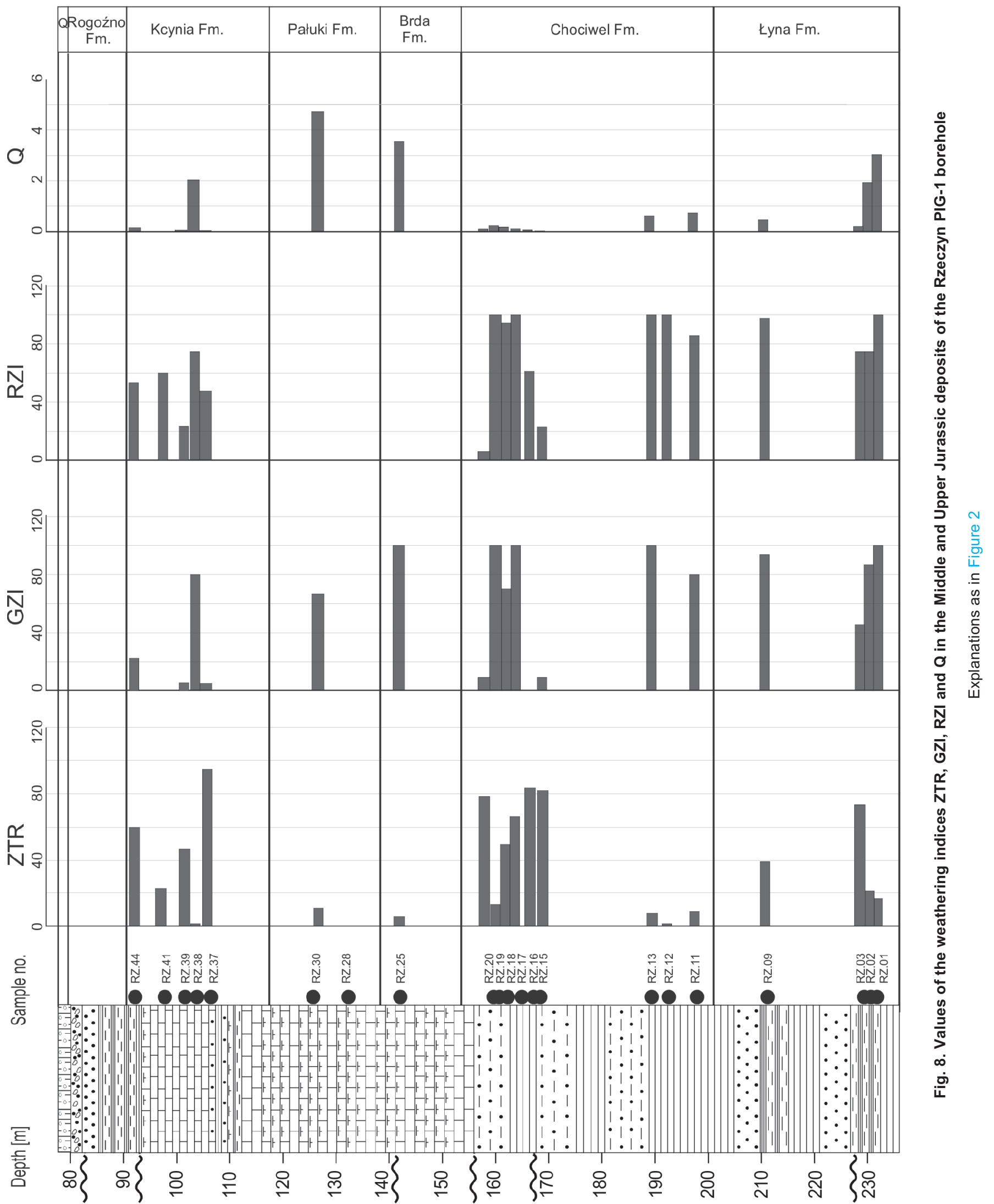


ering and transportation for variable timespans. This is shown by the different degrees of rounding and weathering, e.g. of zircon or garnet, seen within individual samples (Figs. 5 and 6).

Owing to the location of the Rzeczyn PIG-1 borehole in the northern part of the Jurassic epicontinental sea, supply of sediments may have taken place from the NW, N or NE (Fig. 9). Transport of sediments from the south, though, is unlikely due to the large distance from the source areas (Pieńkowski et al., 2008; Matyja et al., 2010), and so a southern location of potential source areas is excluded from our discussion of the provenance of deposits in the Rzeczyn PIG-1 succession.

NORTHWESTERN PROVENANCE OF HEAVY MINERALS

A NW and W direction of supply to the northwestern part of the Polish Basin seems particularly important in the Middle Jurassic for the following reasons: (1) the distance to potential source areas to the east of the site analysed was considerably greater, and (2) the morphology of the basin bottom did not favour supply from the east (Dadlez, 2003; Pieńkowski et al., 2016). Supply from that direction may have been significant in the Late Jurassic (Fig. 9). Potential source areas of the deposits supplied to the northern part of the Middle and Upper Jurassic epicontinental sea should be sought for e.g. in the eroded Ringkøbing-Fyn (RFH) and Skurup (SH) highs, located to the north-west of the borehole analysed in present-day Denmark and northern Germany (Fig. 9). The RFH is subdivided by tectonic grabens into three smaller structural highs, i.e. Grindsted, Glamsbjerg and Møn, and separates the Norwegian-Danish Basin in the north from the North German Basin in the south (Olivarius et al., 2015). In the RFH, Cretaceous deposits are generally underlain by a thick succession of Triassic strata, represented mainly by claystones with subordinate sandstones. In turn, Jurassic rocks are known only from a few localities within grabens separating the structural highs (Olivarius et al., 2015). Triassic strata are thickest within the grabens, while in the interior of the highs they are much thinner. This suggests considerable erosion of Triassic deposits, that probably occurred during the Jurassic when the RFH was subject to constant uplift (Pieńkowski et al., 2008; Rasmussen, 2009; Olivarius et al., 2015). Erosion reduced the Triassic to Lower Jurassic sedimentary cover. By contrast, Nielsen (2003) suggested that during the Middle and Late Jurassic, the RFH functioned as a low-relief paralic hinterland. In that case erosion could have been restricted in situ chemical weathering may have been enhanced, to produce large amounts of sediment capable of being subsequently transported by fluvial and other processes. However, it seems that the surface of the RFH exposed to erosion was too small to be the only source of material supplied to the NW part of the Polish Basin. Moreover, according to Nielsen (2003), the RFH was permanently flooded in the Early Jurassic due to steady subsidence, and therefore if the top of the $\mathrm{RFH}$ was below wave base, its erosion would be restricted or negligible. Additionally, in the Callovian, shallow-water conditions are recorded in Germany after a major sea level fall, which resulted in the development of many local basins and highs separating them. Therefore it is unlikely that the sediment was supplied from the NW (Fig. 9). The only remaining possibility is the development of salt diapirs in the Oxfordian in NW Germany, which could have led to erosion of the tops of salt structures, providing a NW sediment source for deposits in the Rzeczyn PIG-1 borehole (Pieńkowski et al., 2008). In those regions erosion could have reached down to the Lower Jurassic. In Lower Jurassic strata Maliszewska $(1967,1974)$ recorded considerable variability in the heavy mineral composition of the
$0.06-0.20 \mathrm{~mm}$ fraction from sections located on the south-western slope of the basin. Apart from zircon, tourmaline and opaque minerals, the association contains also garnet, i.e. comprises minerals which have been noted in the Rzeczyn PIG-1 borehole. According to Pieńkowski et al. (2008), their source area comprised rocks eroded from the Fore-Sudetic Monocline. However, this does not explain the sediment source for the Łyna Formation (Fig. 9).

The fullest record of the NW source area comes from analysis of the Lower to Upper Triassic Skagerrak Formation, which is present on the Skagerrak-Kattegat Platform (Olivarius and Nielsen, 2016). Deposition of these strata took place in an arid to semi-arid climate (Bertelsen, 1980; McKie et al., 2010). Today, in dune sediments of arid and hot deserts, opaque minerals prevail in the heavy mineral associations (Barczuk and Dłużewski, 2003). A similar pattern was observed in the eastern part of the Skagerrak Formation, which is dominated by Ti-magnetite accompanied by ilmenite, chromite and leucoxite. Among transparent minerals, garnet, rutile and mafic minerals (e.g., amphibole and pyroxene - not separately distinguished) are very rare. Zircon and tourmaline, which are important components of the Łyna, Chociwel and Kcynia formations in the Rzeczyn PIG-1 succession (Fig. 4), were not observed in the Skagerrak Formation at all.

In the middle part of the Skagerrak Formation, the heavy mineral association contains zircon and larger amounts of rutile, but without garnet. The composition of heavy minerals in the western part of the Skagerrak Formation is more variable, with epidote, garnet and mafic minerals (Olivarius and Nielsen, 2016). A similar composition of heavy minerals was observed in the Precambrian basement and Paleozoic rocks of the RFH (Olivarius et al., 2015). However, zircon dating shows that rocks of the Precambrian basement and the Paleozoic were not subject to erosion during the accumulation of the Triassic strata (Olivarius and Nielsen, 2016). A similar conclusion were reached by Paul et al. (2008) following the analysis of isotopic cooling ages of detrital white micas.

As with the Triassic deposits, none of the sections analysed by Olivarius et al. (2015) contains epidote or tourmaline, which were recorded throughout the Rzeczyn PIG-1 succession. A similar pattern is present with garnet and zircon (Fig. 4). Therefore, it may be deduced that the source of tourmaline, zircon and partly garnet lies beyond the RFH area. This is shown by the values of the provenance indices, particularly $Q$ and GZI, which in the Łyna and Brda formations and at the base of the Kcynia Formation attain high values (>1). According to Fay (1975), this may indicate a "Fennoscandian", i.e. northern, direction of sediment supply. Additionally, higher values of the ZTR index, particularly in the Łyna, Chociwel and Kcynia formations (Fig. 8), point to erosion of strata that were characterized by extensive recycling of ancient sedimentary successions coupled locally with hydraulic sorting effects (Garzanti and Andó, 2007; Komar, 2007).

The heavy mineral associations among different formations of the Rzeczyn PIG-1 succession, suggest that sediment supply to the northern part of the Middle and Late Jurassic sea could have been supplied from the NW during the accumulation of each of them, but was not their only source (Fig. 9). Erosion of Triassic deposits could have supplied mainly opaque minerals, e.g. detrital ilmenite, which are common in deposits of the Skagerrak Sandstone Formation (Weible and Friis, 2007; Olivarius and Nielsen, 2016). Their presence was linked to oxidation conditions in the arid to semi-arid Triassic climate, and the presence of reduction spots/areas and occasional larger reduced areas in the red bed host (Weibel, 1998; Weibel and 


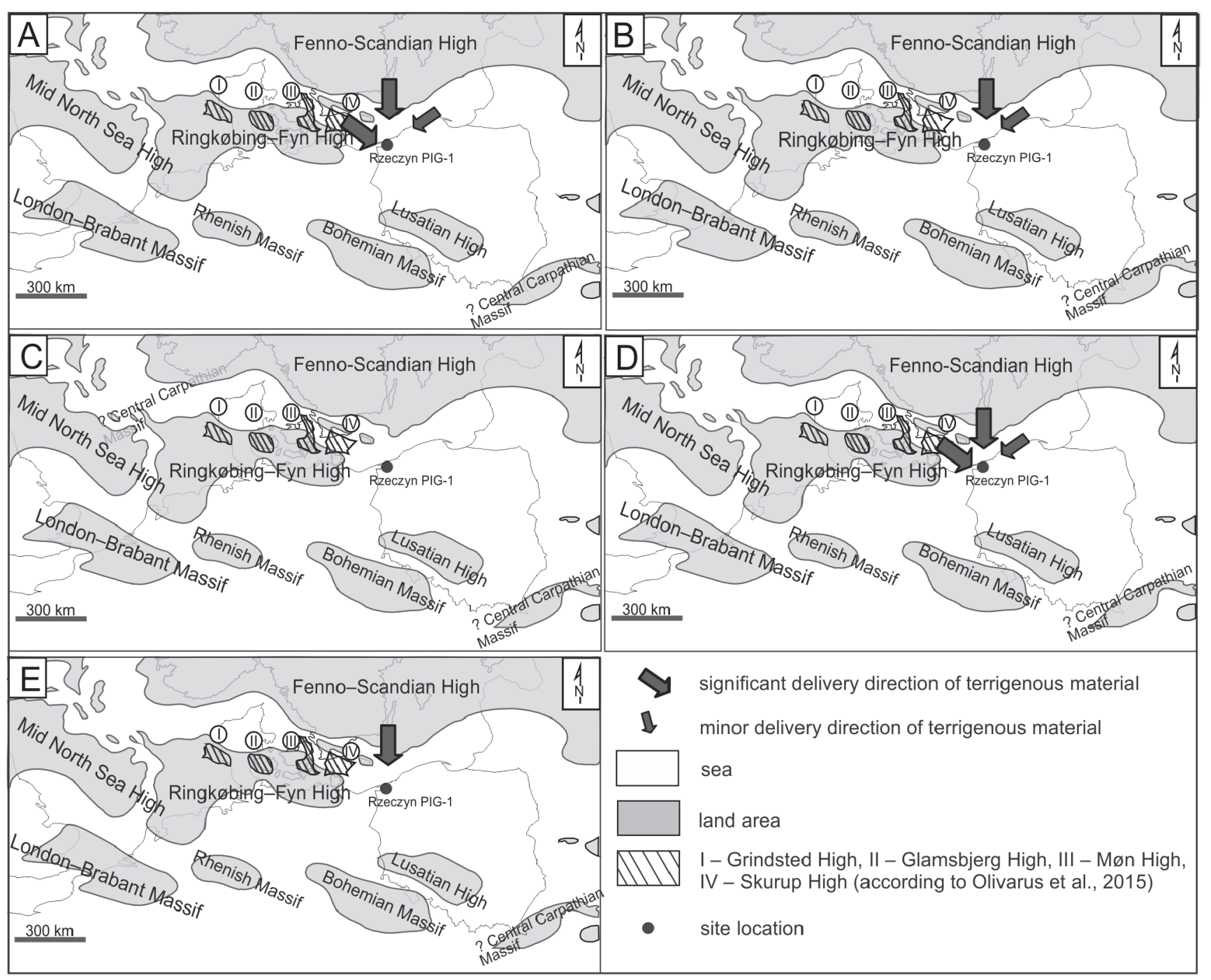

Fig. 9. Directions of sediment supply to the NW part of the epicontinental basin during deposition of the following formations: A - Kyna, B - Chociwel, C - Brda, D - Pałuki, E - Kcynia

Friis, 2004, 2007). Therefore, the NW direction could have been of significance during the accumulation of the Brda and Pałuki formations, being responsible for the ilmenite association (Figs. 4 and 9C, D). Moreover, both the Brda and Pałuki formations represent carbonate deposits that accumulated on a near-shore carbonate shelf (Ceranka et al., 2010). Based on a study of the present-day sea floor sands of the Polish Baltic Sea coast, Wajda (1970) noted the highest concentrations of garnet and opaque heavy minerals up to $\sim 10 \mathrm{~km}$ offshore.

If, however, the RFH was the source area for sediments supplied to the NW Polish Basin, it may be inferred that the material eroded on the RFH accumulated in the marginal parts of the basin and then was current-transported to its deeper regions. Therefore, an along-shore current must have been active along the southern margins of the basin. These currents would be responsible for transporting material from the west to the east, including amphibole, garnet, rutile and opaque minerals, common in the RFH. The contribution of this provenance of source material was, however, quite low due to the small area of the RFH. More plausibly, the main source of heavy minerals from the NW and W in the Late Cretaceous was Lower and Middle Jurassic rocks exposed to erosion (Niemczycka, 1999a, b).

\section{NORTHERN PROVENANCE OF HEAVY MINERALS}

The Fennoscandian Shield located to the north of the Rzeczyn PIG-1 borehole could have been an important source of sediments supplied to the northern part of the Jurassic Polish Basin (Fig. 9). On the Fennoscandian Shield, glacial erosion has efficiently removed many pre-glacial landforms and deposits (Hendriks et al., 2007; Fredin et al., 2017; Hall, van Boeckel, 2020), with estimates that Quaternary ice-sheets eroded $\sim 20 \mathrm{~m}$ of sediment from the Baltic Sea basin and $\sim 40 \mathrm{~m}$ from the surrounding areas during the last $1 \mathrm{My}$ (Hall, van Boeckel, 2020). However, pre-Pleistocene deposits are preserved at many localities (Olsen et al., 2012; Fredin et al., 2017), particularly related with fracture zones as remnants of the deeply weathered basement (Olsen et al., 2012). Ziegler (1978) indicated that the 
southernmost part of the Fennoscandian Shield was covered by Triassic deposits representing the same sedimentary setting as for the RFH. Based on mica dating, Paul et al. (2008) concluded that during the Early and Middle Jurassic, the supply of material to the northern part of the epicontinental sea could have been from the north. This view was also expressed by Ziegler (1978, 1990) as well as Maliszewska (1967) and Niemczycka (1999a, b). However, due to a lack of comparative data on the composition of heavy minerals from Mesozoic and older strata overlying the crystalline basement of the Fennoscandian Shield, it is not possible to determine the role of a northern source of sediment supply to the northern part of the Polish Basin. And, it is not possible to state which mineral association such a direction might correspond to.

Chemical weathering under subtropical conditions took place extensively in the Triassic (Fredin et al., 2017), Jurassic and Early Cretaceous (Lidmar-Bergström et al., 1999; Olsen et al., 2012), as shown by palaeoclimatic data indicating that the Jurassic was warm and for the most part humid (Chandler et al., 1992; Dromart et al., 2003; Pieńkowski et al., 2008; Pieńkowski and Waksmundzka, 2009; Hesselbo and Pieńkowski, 2011). Dera et al. (2011) postulated climate cooling at the Callovian/Oxfordian boundary. In such warm and humid conditions, elimination of less stable heavy minerals (e.g., amphibole, pyroxene, and even garnet) and enrichment in more stable minerals resistant to chemical weathering could have taken place. Studies of glacial till of the Saalian and Weichselian glaciations in Lithuania (Vareikienè et al., 2007), Poland (Woronko et al., 2013), and the Netherlands (Rappol and Stoltenberg, 1985) indicate that these deposits are particularly rich in amphibole and garnet. Vareikienè et al. (2007) suggested that these minerals originated from the Fennoscandian Shield, which includes Archean-Proterozoic crystalline rocks and younger recycled sedimentary rocks ranging from the Cambrian to the Paleogene.

High values of the $Q$ index, registered in all formations of the Rzeczyn PIG-1 succession (Fig. 8), clearly point to erosion of rocks of the Fennoscandian Shield (Fig. 9). The presence of angular grains of garnet and euhedral zircons ("first-cycle" grains) in each of the formations analysed (Figs. 5 and 6), supports the interpretation of Fay (1975), at the same time indicating that fresh weathering products supplied from the north to the Jurassic sea were an important source throughout accumulation of the deposits analysed. This suggests that rocks of the Fennoscandian Shield must have been subject to erosion in the Late Jurassic. According to Ahlberg et al. (2003), the crystalline basement was re-exposed and affected by weathering in southernmost Sweden in the Triassic and the hilly western margin of the Bothnian Sea was expposed in the latest Jurassic (Mark et al., 2014). Similar conclusions were drawn by Maliszewska (1967) and Pieńkowski (2004), who suggested, however, that these events could have taken place in the Early Jurassic. Moreover, erosion must have affected Triassic, Lower Jurassic and older strata, which contained "multi-cycle" grains, as shown by the presence of "multi-cycle" zircon grains with rounded to subrounded shapes (Fig. 6), as well as a high contribution of tourmaline and rutile (Fig. 4). However, if Triassic rocks overlying the Fennoscandian Shield represent similar facies to the Triassic of the RFH, explaining the presence of zircon and tourmaline in each formation still remains a problem, particularly in the Chociwel and Kcynia formations, where the content of these minerals is very high (Fig. 7). This direction would be dominant during deposition of the Pałuki and Chociwel formations, in which the contribution of ultrastable minerals is very low, and garnet and amphibole dominate. In the Lower Jurassic strata of the MPT axis Maliszewska (1967) found a clear domination of opaque minerals, zircon, tourmaline and rutile, but not garnet. Strata of this age in the Bartoszyce IG 1 and Goldap IG 1 boreholes (Peribaltic Syneclise) contain garnet and dysthene apart from ultrastable minerals (Maliszewska, 1974, 1997) and their source areas and rocks occur in the distant Baltic Shield. The same compositions of heavy minerals was found in the Middle Jurassic deposits (Maliszewska and Dayczak-Calikowska, 1997). Niemczycka (1999a, b) also stated that the land area to the north was enlarged in the Kimmeridgian.

Petrographic analysis of clastic rocks from the Rzeczyn PIG-1 borehole (Ceranka et al., 2010) has indicated that their source sediments were derived from erosion of a stable craton. Analysis of the contents of strontium isotopes (Żywiecki et al., 2010) showed that deposits of the Łyna and Chociwel formations (Callovian and Oxfordian) could have had a different source than the Brda, Pałuki and Kcynia formations (Late Oxfordian, Kimmeridgian and Tithonian). Sea water composition was uniform in the Boreal and Tethyan domains in the European Platform during the deposition of the Łyna and Chociwel formations. Furthermore, the siltstone-sandstone character of the sediments building both formations points to proximity to an exposed landmass. By comparison, deposition of the Brda, Pałuki and Kcynia formations took place in sea water enriched in ${ }^{87} \mathrm{Sr}$, which was related to a change of sediment source (Fig. 9C-E). This change was linked with the supply of material from the north, from the uplifted Scandinavian area, and erosion of magmatic rocks (Żywiecki et al., 2010). Moreover, close to the end of the Jurassic (Middle and Late Tithonian), an equatorial arid zone extended across Europe (Pieńkowski et al., 2008). This phenomenon was a Late Jurassic orographic effect, caused by collision of the Cimmeride mountain chain with Eurasia (Hallam, 1994). Cooler climate conditions are correlated with this arid phase, combined with a sea level lowstand and lower seawater temperatures (Ruffell and Rawson, 1994; Schudack, 1999, 2002). Sea level fall in the epicontinental Polish Basin is consistent with the sandy Chociwel Formation (Fig. 2). The lowest temperatures occurred around the Callovian-Oxfordian boundary and just before the end of the Jurassic (Pieńkowski et al., 2008). Temperature fall was accompanied by a decrease in evapotranspiration, followed by increased fluvial activity in the catchment area, causing more intense and deeper erosion. However, the spread of arid conditions could have caused a higher contribution of opaque minerals to the sediments, as observed in the Brda and Pałuki formations (Fig. 4), perhaps correlated with major episodes of sea level rise that took place in the Middle Callovian and from the Late Oxfordian to the Kimmeridgian (Pieńkowski et al., 2008).

NORTHEASTERN PROVENANCE OF HEAVY MINERALS

Radlicz (1997) suggested that in the Late Jurassic (Oxfordian to Kimmeridgian), sediment supply to the Polish epicontinental basin was from the north-east (Fig. 9). This sediment was determined as an amphibole-basaltoid association, however without indication of the age of rocks eroded in the source area.

An source area to the east or north-east cannot be excluded, as the RFH deposits eroded during the Middle and Late Jurassic lack or contain only a small amount of ultrastable minerals - zircon and tourmaline, and minerals moderately resistant to chemical weathering, such as garnet (Olivarius et al., 2015). In turn, these minerals are dominant in the Łyna, Chociwel and Kcynia formations in the Rzeczyn PIG-1 succession (Figs. 4 and 7). Devonian sandstones occurring in present-day Latvia, Lithuania and Estonia are rich in these minerals, particularly the Middle Devonian Gauja Regional Stage Sietiňi 
Formation (Blākse et al., 2013; Järvelill et al., 2019). Additionally, this was a land area during the Late Jurassic (Ziegler, 1978), especially during the expansion of desert climate conditions. Rivers draining the landmass could have eroded Devonian rocks and supplied material to the Polish Basin, particularly because Jurassic alluvial deposits have been noted in western Latvia, supporting the continental character of these deposits and a functional drainage system (Blāke et al., 2013). The tourmaline-zircon-garnet association may be linked with this transport direction. It seems that the NE direction of supply was of considerable significance during the deposition of the Chociwel and Łyna formations (Figs. 4, 7 and 9), particular because zircon from both formations has a similar roundness (Fig. 6). The source of zircon in the Łyna Formation, where it differs in the degree of rounding, remains an unsolved issue. The degree of rounding is much lower, the abundance of euhedral grains is higher and the abundance of well-rounded grains is lower than in any other formation from the Rzeczyn PIG-1 succession. Broken zircons are also common (Fig. 6). This indicates that erosion of freshly deposited rocks, not subject to multiple recycling, or weathering crystalline rock covers, played an important role during the accumulation of the Kcynia Formation (Fig. 9E). On the other hand, the zircon-rutile-ilmenite association of the Kcynia Formation indicates that such enrichment may have been caused by chemical weathering of crystalline rocks. In this case, it is improbable that the grains could have been derived from the erosion of Devonian sandstones (Fig. 9E). Material supply from this direction would have been possible only with marine currents flowing from the east to the west at that time.

\section{EFFECT OF SEA LEVEL CHANGES}

Based on biostratigraphic (ammonite and dinoflagellate cysts), chronostratigraphic and lithostratigraphic analysis, many stratigraphic gaps have been identified in the Rzeczyn PIG-1 succession (Fig. 2), in each case linked with a modification of the heavy minerals association. This unequivocally indicates that in the Late Jurassic a cyclic switching of source areas must have taken place, even during the accumulation of a single formation e.g. Łyna Formation (Fig. 4). This must have been linked with sea level oscillations, registered in various parts of the world during the Middle and Late Jurassic (Šimkevičius, 1998; Haq and Al-Qahtani, 2005; Pieńkowski et al., 2008; Haq, 2017), and reflected in the variability of lithofacies in the succession analysed (Fig. 4). Sea level oscillations must have partly depended on local and regional tectonics, both in the source areas and in the area where the final accumulation of sediments took place (Dadlez, 2003; Pieńkowski et al., 2008). A direct effect of this process was flooding or exposure of parts of the seabed, that would have redirected marine currents and changed sediment source areas. In such conditions there would have been (1) significant expansion of the catchment area, (2) increase of river gradient, and (3) intense erosion in the river channel and on catchment slopes, resulting from the lowering of base level, and thus (4) erosion of earlier inaccessible strata in the surrounding landmasses. All these processes were prolonged.

In the intervals representing the stratigraphic disconformities recording periods of maximum regression (Fig. 3; Pieńkowski et al., 2008), the study area must have been land, on the surface of which erosion of the sediments and their removal to the adjacent coastal sea must have taken place (close-distance effect). At that time, the erosion rate would reflect the efficiency of the transport processes and removal of the exposed material. This caused successive denudation of the exposed land surface and reintroduction of older sediments into the cycle. The prominent change of sediment provenance must have been associated with retrogressive erosion in the sedimentary source area caused by rapid base-level fall in the sedimentary basin, as with the Lower Jurassic of the same basin. Bed and backward erosion increased, resulting in destruction of strata of different age and origin (Pieńkowski, 2004). Additionally, when these sediments appeared at coastlines, attrition of the heavy mineral grain surfaces must have increased. Another effect may have been the reorganisation or even restriction of the earlier existing source areas.

By contrast, significant sea level rise could have isolated earlier existing source areas and increased distances from the source area (depth-far distance effect). Physical sorting of heavy minerals with regard to density, grain-size and shape would have taken place (Komar, 2007) along continental margins and in littoral settings (Cascalho, 2019). Such a situation could have occurred each time when the marine sedimention of e.g. clays took place in deeper parts of the basin (Fig. 3).

Analysis of the succession shows that the seabed could have represented a land area (close-distance effect) at least five times during the accumulation of the deposits studied. The first time was during the deposition of the Łyna Formation as indicated by the change in lithology from marl and claystone into sandstone (Fig. 3). This is correlated with a regressive phase that took place in the Late Callovian (Pieńkowski et al., 2008), that caused cut-off from areas supplying large amounts of garnet and kyanite, and a sudden change from a garnet-rutile-kyanite association into a rutile-ilmenite association (Fig. 4). The source area rich in garnet and kyanite was active not only during the Late Callovian, but also during the accumulation of the basal parts of the Chociwel Formation. This is the first sandy formation in the Rzeczyn PIG-1 succession (Figs. 2 and 3). Ceranka et al. (2010) proposed that its deposition took place on an open siliciclastic shelf. However, its sandy character rather points to deposition near coastal margins. Moreover, the presence of a stratigraphic gap in the upper part of the Chociwel Formation (Fig. 2) suggests marine regression after the Mariae Zone and erosion of this part of the seabed in subaerial conditions. This is correlated with a sea level lowstand in the Late Oxfordian, which is consistent with a generally similar heavy mineral association below and above the stratigraphic gap (Fig. 3). This also indicates that the exposed land area was the main source area for this part of the formation due to its proximity (close-distance effect). Moreover, gaps detected in the Rzeczyn PIG-1 borehole correspond to regression phases in the Middle and Late Kimmeridgian and the Late Tithonian (Fig. 3; Pieńkowski et al., 2008).

Sea level rise, though, caused a change not only in sedimentary conditions but also increased the distance to potential source areas. One of the major episodes of sea level rise took place in the Middle Callovian and Late Oxfordian to Kimmeridgian (Pieńkowski et al., 2008). There was no supply of material in the fraction analysed $(0.125-0.250 \mathrm{~mm})$ to deeper parts of the sea basin (depth-far distance effect). Formation of authigenic minerals, e.g. apatite and pyrite, took place in the deeper parts of the basin, as shown by the heavy mineral association in the Chociwel and Brda Formations (Fig. 2).

\section{CONCLUSIONS}

Heavy mineral analysis and weathering indices calculated for Middle and Upper Jurassic deposits that accumulated in the 
epicontinental sea that covered the Pomeranian segment of the MPT (NW Poland) show a large variability in the composition of the heavy mineral association in each formation distinguished: Łyna, Chociwel, Brda, Pałuki and Kcynia. The main clastic supply directions were from the $\mathrm{N}$ and NW, and to a lesser degree from the NE. Most probably, clastic material was supplied from all three directions during the accumulation of each of the formations, but in varying proportions. During deposition of the Łyna, Chociwel, Pałuki and Kcynia formations the prevailing supply seems to have been from the north, from exposed deposits and crystalline rocks of the Fennoscandian Shield and areas located to the north-west. A minor role was played by supply from the NE. The Brda Formation is very poor in heavy detrital grains and rich in authigenic minerals, which suggests cut-off from supply of clastic material.

Rocks that were earlier subject to multiple recycling, and so very mature with respect to the heavy mineral composition and rich in ultrastable minerals, were subject to erosion. They included mainly Triassic rocks and to a lesser degree fresh weathering covers of crystalline rocks and Devonian sandstones. The main reason for changes to the composition of the heavy mineral associations were sea level fluctuations, which led to drastic changes in the palaeogeography of the catchment zones of the source areas. During regressions, parts of the basin became exposed and eroded. This resulted in a close-distant effect with respect to the study area. In turn, marine transgressions caused increase of water depth and in the extent of the marine realm, resulting in a depth-far distance effect.

Acknowledgements. A. Żylińska (University of Warsaw, Poland) is thanked for English proof-reading that significantly improved our manuscript. Thanks are due to the reviewers $D$. Salata and G. Pieńkowski for valuable advice and useful comments on the manuscript.

\section{REFERENCES}

Ahlberg, A., Olsson, I., Simkevicius, P., 2003. Triassic-Jurassic weathering and clay mineral dispersal in basement areas and sedimentary basins of southern Sweden. Sedimentary Geology, 161: $15-29$.

Andò, S., Garzanti, E., Padoan, M., Limonta, M., 2012. Corrosion of heavy minerals during weathering and diagenesis: a catalog for optical analysis. Sedimentary Geology, 280: 165-178.

Barczuk, A., Dłużewski, M., 2003. Skład mineralno-litologiczny jako podstawa do określenia źródła i wskaźnik stopnia eolizacji wydmowych (in Polish). In: Współczesna ewolucja środowiska przyrodniczego regionu Coude du Dra (południowe Maroko) i jej wpływ na warunki życia ludności autochtonicznej (ed. M. Dłużewski): 103-120. Wydawnictwo Akademickie Dialog, Warszawa.

Barski, M., Matyja, B.A., 2010. Biostratygrafia (in Polish). In: Dokumentacja geologiczna otworu badawczego Rzeczyn PIG-1 (eds. B.A. Matyja, M. Barski, T. Ceranka, R. Dobrecki, J. Dzierżek, M. Jackiewicz, O. Rosowiecka and M. Żywiecki): 21-23. Państwowy Instytut Geologiczny.

Barth, G., Pieńkowski, G., Zimmermann, J., Franz, M., Kuhlmann, G., 2018. Palaeogeographical evolution of the Lower Jurassic: high-resolution biostratigraphy and sequence stratigraphy in the Central European Basin. Geological Society Special Publications, 469: 341-369.

Bateman, R.M., Calt, J.A., 2007. Provenance and paleoenvironmental interpretation of superficial deposits with particular reference to post - depositional modification of heavy mineral assemblages. Developments in Sedimentology, 58: 151-188.

Bertelsen, F., 1980. Lithostratigraphy and depositional history of the Danish Triassic. Danmarks Geologiske Undersøgelse Serie $B, 4,59$.

Blāķe, D., Tovmasjana, K., Stinkulis, Ģ., 2013. Depositional environment of the Devonian quartz sandstones in the Bāle Sand Pits. Material Science and Applied Chemistry, 29: 14-20.

Cascalho, J., 2019. Provenance of heavy minerals: a case study from the WNW Portuguese continental margin. Minerals, 9, 355: $1-33$.

Cascalho, J., Fradique, C., 2007. The sources and hydraulic sorting of heavy minerals on the northern Portuguese continental margin. Developments in Sedimentology, 58: 75-110.

Ceranka, T., Żywiecki, M., Jackiewicz, M., 2010. Analiza sedymentologiczna (in Polish). In: Dokumentacja geologiczna otworu badawczego Rzeczyn PIG-1 (eds. B.A., Matyja, M. Barski, T. Ceranka, R. Dobrecki, J. Dzierżek, M. Jackiewicz, O.
Rosowiecka and M. Żywiecki): 38-90. Państwowy Instytut Geologiczny.

Chandler, M.A., Rind, D., Ruedy, R., 1992. Pangaean climate during the Early Jurassic: GCM simulations and the sedimentary record of paleoclimate. GSA Bulletin, 104: 543-559.

Dadlez, R., 1997. Epicontinental basins in Poland. Devonian to Cretaceous - relationships between the crystalline basement and sedimentary infill. Geological Quarterly, 41 (4): 419-432.

Dadlez, R., 1998. Nota objaśniająca (in Polish). In: Palaeogeographical Atlas of the Epicontinental Permian and Mesozoic in Poland (eds. R. Dadlez, S. Marek and J. Pokorski): 3-6. Państwowy Instytut Geologiczny.

Dadlez, R., 2000. Pomerania Caledonides (NW Poland), fifty years of controversies: a review and new concept. Geological Quarterly, 44 (3): 221-236.

Dadlez, R., 2001. Explanatory note. In: Mid-Polish Trough - Geological Cross Sections. 1:200 000, Warszawa: 19-29.

Dadlez, R., 2003. Mesozoic thickness pattern in the Mid-Polish Trough. Geological Quarterly, 47 (3): 223-240.

Dadlez, R., Marek, S., 1997. Development of the Permian and Mesozoic basins (in Polish with English summary). Prace Państwowego Instytutu Geologicznego, 153: 403-409.

Dadlez, R., Marek, S., Pokorski, J. (eds.), 1998. Palaeogeographical Atlas of the Epicontinental Permian and Mesozoic in Poland. Państwowy Instytut Geologiczny.

Dadlez, R., Marek, S., Pokorski, J., 2000. Geological Map of Poland without Cainozoic Deposits 1:1 000 000, Wydawnictwo Kartograficzne Polskiej Agencji Ekologicznej S.A.

Dadlez, R., Narkiewicz, M., Stephenson, R.A., Visser, M.T.M., van Wees, J.-D., 1995. Tectonic evolution of the Mid-Polish Trough: modelling implications and significance for Central European geology. Tectonophysics, 252: 179-185.

Fay, M., 1975. Heavy mineral analysis of NW German Tertiary Sediments. Report 1, Meeting in Mainz. Project, 124: 47-53.

Fredin, O., Viola, G., Zwingmann, H., Sorcie, R., Brenner, M., Lie, J.-E., Granda, E.M., Müller, A., Margreth, A., Vogt, Ch., Knies, J., 2011. The inheritance of a Mesozoic landscape in western Scandinavia. Nature Communications, 8 (14879): 1-11.

Garzanti, E., Andò, S., 2007. Heavy mineral concentration in modern sands: implications for provenance interpretation. Developments in Sedimentology, 58: 517-545.

Garzanti, E., Doglioni, C., Vezzoli, G., Andò, S., 2007. Orogenic belts and orogenic sediment provenance. The Journal of Geology, 115: 315-334 
Garzanti, E., Andò, S., Limonta, M., Fielding, L., Najman, Y., 2018. Diagenetic control on mineralogical suites in sand, silt, and mud (Cenozoic Nile Delta): implications for provenance reconstructions. Earth-Science Reviews, 185: 122-139.

Hall, A., van Boeckel, M., 2020. Origin of the Baltic Sea basin by Pleistocene glacial erosion. GFF, doi: 10.1080/11035897. 2020.1781246

Hallam, A., 1994. Jurassic climates as inferred from the sedimentary and fossil record. In: Palaeoclimates and Their Modeling (eds. J.R.L. Allen, B.J. Hoskins, B.W. Sellwood, R.A. Spicer and P.J. Valdes): 79-88. Chapman and Hall, London.

Haq, B.U., 2017. Jurassic sea-level variations: a reappraisal. GSA Today, 28: 4-10.

Haq, B.U., Al-Qahtani, A.M., 2005. Phanerozoic cycles of sea-level change on the Arabian Platform. GeoArabia, 10: 127-160.

Hendriks, B., Andriessen, P., Huigen, Y., Leighton, C., Redfield, T., Murrell, G., Gallagher, K., Nielsen, S.B., 2007. A fission track data compilation for Fennoscandia. Norwegian Journal of Geology, 87: 143-155.

Hesselbo, S.P., Pieńkowski, G., 2011. Stepwise atmospheric carbon-isotope excursion during the Toarcian Oceanic Anoxic Event (Early Jurassic, Polish Basin). Earth and Planetary Science Letters, 301: 365-372.

Hubert, J.F., 1962. A zircon-tourmaline-rutile maturity index and the interdependence of the composition of the heavy mineral assemblages with the gross composition and texture of sandstones. Journal of Sedimentary Petrology, 32: 440-450.

Järvelill, J.-I., Kallaste, T., Kleesment, A., Pajusaar, S., Raukas, A., 2019. Provenance of heavy minerals in the Quaternary deposits of the Lemme outcrop, Estonia, based on optical microscopy, X-ray diffractometry and scanning electron microscope microanalysis. Estonian Journal of Earth Sciences, 68: 76-87.

Komar, P.D., 2007. The entrainment, transport and sorting of heavy minerals by waves and currents. Developments in Sedimentology, 58: 3-48.

Komar, P.D., Clemens, K.E., Li Z., Shih, S., 1989. The effects of selective sorting on factor analyses of heavy-mineral assemblages. Journal of Sedimentary Research, 59: 590-596.

Królikowski, C., Petecki, Z., Żółtowski, Z., 1999. Main structural units in the Polish part of the East-European Platform in the light of gravimetric data (in Polish with English summary). Biuletyn Państwowego Instytutu Geologicznego, 386: 5-58.

Krzywiec, P., 2002. Mid-Polish Trough inversion - seismic examples, main mechanisms, and its relationship to the Alpine-Carpathian collision. EGU Stephan Mueller Special Publication Series, 1: 151-165.

Krzywiec, P., 2006. Geodynamic and tectonic control on evolution of foreland basins, with references to the Carpathian Foredeep Basin (in Polish with English summary). Przegląd Geologiczny, 54: 404-412.

Kutek, J., 2001. The Polish Permo-Mesozoic Rift Basin. Mémoires du Musée Histoire Naturelle, 186: 213-236.

Kutek, J., Matyja, B.A., Wierzbowski, A., 1984. Late Jurassic biogeography in Poland and its stratigraphical implications. In: International Symposium on Jurassic Stratigraphy, Erlangen 1984, (eds. O. Michelsen and A. Zeiss). Geological Survey of Denmark, Symposium 3.

Lamarche, J., Bergerat, F., Lewandowski, M., Mansy, J.L., Świdrowska, J., Wieczorek J., 2002. Variscan to Alpine heterogenous palaeo-stress above a major Paleozoic suture in the Carpathian foreland (southeastern Poland). Tectonophysics, 357: 55-80.

Lidmar-Bergström, K., Olsson, S., Roaldset, E., 1999. Relief features and palaeoweathering remnants in formerly glaciated Scandinavian basement areas. IAS Special Publication, 27: 275-301.

Maliszewska, A., 1967. The petrography of the Liassic deposits in the Polish Lowland Area (in Polish with English summary). Biuletyn Instytutu Geologicznego, 207: 67-155.
Maliszewska, A., 1974. Bartoszyce IG-1, Gołdap IG-1 (in Polish). Profile Głębokich Otworów Wiertniczych Instytutu Geologicznego, 14: 283-285.

Maliszewska, A., 1997. Jura dolna - charakterystyka petrograficzna (in Polish). Prace Państwowego Instytutu Geologicznego, 153: 206-208.

Maliszewska, A., Dayczak-Calikowska, K., 1997. Jura środkowa - charakterystyka petrograficzna (in Polish). Prace Państwowego Instytutu Geologicznego, 153: 263-282.

Mange, M.A., Wright, D.T., 2007. Introduction and overview. Developments in Sedimentology, 58: XXVII-XLIV.

Marcinowski, B, Mycielska-Dowgiałło, E., 2013. Heavy-mineral analysis in Polish investigations of Quaternary deposits: a review. Geologos, 19: 5-23.

Marek, S., Pajchlowa, M. (eds.), 1997. The epicontinental Permian and Mesozoic in Poland (in Polish with English summary). Prace Państwowego Instytutu Geologicznego, 153.

Mark, D.F., Lindgren, P., Fallick, A.E., 2014. A high-precision ${ }^{40} \mathrm{Ar} /{ }^{39} \mathrm{Ar}$ age for hydrated impact glass from the Dellen impact, Sweden. Geological Society Special Publications, 378: 349-366.

Masłowska, M., Michałowska, M., 2004. Heavy minerals composition of sediments underlying the Quaternary in the northwestern Poland (in Polish with English summary). Biuletyn Państwowego Instytutu Geologicznego, 407: 89-111.

Matyja, B.A., 2010a. Chronostratygrafia (in Polish). In: Dokumentacja geologiczna otworu badawczego Rzeczyn PIG-1 (eds. B.A. Matyja, M. Barski, T. Ceranka, R. Dobrecki, J. Dzierżek, M. Jackiewicz, O. Rosowiecka and M. Żywiecki): 23-25. Państwowy Instytut Geologiczny.

Matyja, B.A., 2010b. Litostratygrafia (in Polish). In: Dokumentacja geologiczna otworu badawczego Rzeczyn PIG-1 (eds. B.A. Matyja, M. Barski, T. Ceranka, R. Dobrecki, J. Dzierżek, M. Jackiewicz, O. Rosowiecka and M. Żywiecki): 16-20. Państwowy Instytut Geologiczny.

Matyja, B.A., Barski, M., Ceranka, T., Dobrecki, R., Dzierżek, J., Jackiewicz, M., Rosowiecka, O., Żywiecki, M., 2010. Dotychczasowe prace i określenie zadania geologicznego (in Polish). In: Dokumentacja geologiczna otworu badawczego Rzeczyn PIG-1 (eds. B.A. Matyja, M. Barski, T. Ceranka, R. Dobrecki, J. Dzierżek, M. Jackiewicz, O. Rosowiecka and M. Żywiecki): 5. Państwowy Instytut Geologiczny.

McKie, T., Williams, B., 2009. Triassic palaeogeography and fluvial dispersal across the northwest European basins. Geological Journal, 44: 711-741.

Michelsen, O., 1997. Mesozoic and Cenozoic stratigraphy and structural development of the Sorgenfrei-Tornquist Zone. Zeitschrift der Deutschen Geologischen Gesellschaft, 148: 33-50.

Morton, A.C., 2007. The role of heavy mineral analysis as a geosteering tool during drilling of high-angle weels. Developments in Sedimentology, 58: 1123-1144.

Morton, A.C., Hallsworth, C.R., 1994. Identifying provenance specific features of detrital heavy mineral assemblages in sandstones. Sedimentary Geology, 90: 241-256.

Morton, A.C., Hallsworth, C.R., 1999. Processes controlling the composition of heavy minerals assemblages in sandstones. Sedimentary Geology, 124: 3-29.

Mounteney, I., Burton, A.K., Farrant, A.R., Watts, M.J., Kemp, S.J., Cook, J.M., 2018. Heavy mineral analysis by ICP-AES a tool to aid sediment provenancing. Journal of Geochemical Exploration, 184: 1-10.

Mycielska-Dowgiałło, E., 2007. Metody badań cech teksturalnych osadów klastycznych i wartość interpretacyjna wyników (in Polish). In: Badania cech teksturalnych osadów czwartorzędowych i wybrane metody oznaczania ich wieku (eds. E. Mycielska-Dowgiałło and J. Rutkowski): 95-180. WSWPR, Warszawa.

Nielsen, L.H., 2003. Late Triassic-Jurassic development of the Danish Basin and the Fennoscandian Border Zone, southern 
Scandinavia. Geological Survey of Denmark and Greenland Bulletin, 1: 459-526.

Niemczycka, T., 1997a. Jura górna - sedymentacja, paleogeografia, paleotektonika (in Polish). Prace Państwowego Instytutu Geologicznego, 153: 322-326.

Niemczycka, T. 1997b. Przedolnokredowa (riazańsko-cenomańska) powierzchnia na Niżu Polskim Jura górna sedymentacja, paleogeografia, paleotektonika (in Polish). Prace Państwowego Instytutu Geologicznego, 153: 327-330

Olesen, O., Bering, D., Brönner, M., Dalseg, E., Fabian, K., Fredin, O., Gellein, J., Husteli, B., Magnus, Ch., Rønning, J.S., Solbakk, T., Tønnesen, J.F., Øverland, J.A., 2012. Tropical Weathering in Norway. TWIN Final Report. Geological Survey of Norway.

Olivarius, M., Nielsen, L.H., 2016. Triassic paleogeography of the greater eastern Norwegian-Danish Basin: constrains from provenance analysis of the Skagerrak formation. Marine and Petroleum Geology, 69: 168-182.

Olivarius, M., Friis, H., Kokfelf, T.F, Wilson, J.R., 2015. Proterozoic basement and Palaeozoic sediments in the Ringkøbing-Fyn High characterized by zircon $\mathrm{U}-\mathrm{Pb}$ ages and heavy minerals from Danish onshore wells. Bulletin of the Geological Society of Denmark, 63: 29-44.

Oszczypko, N., Salata, D., 2005. Provenance analyses of the Late Cretaceous-Palaeocene deposits of the Magura Basin (Polish Western Carpathians) - evidence from the heavy minerals study. Acta Geologica Polonica, 55: 237-267.

Paul, J., Wemmer, K., Arendt, H., 2008. Provenance of siliciclastic sediments (Permian to Jurassic) in the Central European Basin. Zeitschrift der Deutschen Gesellschaft für Geowissenschaften, 159: 641-650.

Pieńkowski, G., 2004. The epicontinental Lower Jurassic of Poland. Polish Geological Institute, Special Papers, 12.

Pieńkowski, G., Waksmundzka, M., 2009. Palynofacies in Lower Jurassic epicontinental deposits of Poland - tool to interpret sedimentary environments. Episodes, 32: 21-32.

Pieńkowski, G., Niedźwiecki, G., Waksmundzka, M., 2012. Sedimentological, palynological, and geochemical studies of the terrestrial Triassic-Jurassic boundary in northwestern Poland. Geological Magazine, 149: 308-332.

Pieńkowski, G., Schudack, M.E., Bosák, P., Enay, R., Feldman-Olszewska, A., Golonka, J., Gutowski, J., Herngreen, G.F.W., Jordan, P., Krobicki, M., Lathuiliere, B., Leinfelder, R.R., Michalik, J., Mönning, E., Noe-Nygaard, N., Pálfy, J., Pint, A., Rasser, M.W., Reisdorf, A.G., Schmid, D.U., Schweigert, G., Surlyk, F., Wetzel, A., Wong, T.E., 2008. Jurassic. In: The Geology of Central Europe (ed. T. McCann): 823-922. The Geological Society, London.

Pisarska-Jamroży, M., Van Loon, A.J., Woronko, B., 2015. Sorting of heavy minerals in sediments deposited at a high accumulation rate, with examples from sandurs and an ice-marginal valley in NW Poland. GFF, 137: 126-140.

Poprawa, P., 1997. Late Permian to Tertiary dynamics of the Polish Trough. Terra Nostra, 97: 104-109.

Pożaryski, W., Brochwicz-Lewiński, W., 1978. On the Polish Trough. Geologie en Mijnbouw, 57: 545-557.

Radlicz, K., 1997. Jura górna. Litostratygrafia i litofacje Charakterystyka petrograficzna i sedymentologiczna (in Polish). Prace Państwowego Instytutu Geologicznego, 153: 322-327.

Rappol, M., Stoltenberg, H.M.P., 1985. Compositional variability of Saalian till in The Netherlands and its origin. Boreas, 14: 33-50.

Rasmussen, E.S., 2009. Neogene inversion of the Central Graben and Ringkøbing-Fyn High, Denmark. Tectonophysics, 465: 84-97.

Ruffell, A.H., Rawson, P.F., 1994. Palaeoclimate control on sequence stratigraphic patterns in the Jurassic to mid-Cretaceous, with a case study from Eastern England. Palaeogeography, Palaeoclimatology, Palaeoecology, 110: 43-54.

Ryan, P.D., Mange, M.A., Dewey, J.F., 2007. Statistical analysis of high-resolution heavy mineral stratigraphic data from the Ordovician of western Ireland and its tectonic consequences. Developments in Sedimentology, 58: 465-489.
Salata, D., Uchman, A., 2013. Conventional and high-resolution heavy mineral analyses applied to flysch deposits: comparative provenance studies of the Ropianka (Upper Cretaceous-Paleocene) and Menilite (Oligocene) formations (Skole Nappe, Polish Carpathians). Geological Quarterly, 57 (4): 649-664.

Schudack, M., 1999. Ostracoda (marine/nonmarine) and paleoclimate history in the late Jurassic of Central Europe and North America. Marine Micropaleontology, 37: 273-288.

Schudack, M., 2002. Late Jurassic ostracod biogeography, Stell chemistry, and palaeoclimate in Europe and North America, Abstracts 6th International Symposium on the Jurassic System, Palermo.

Siwy-Będkowska, K., 2009. Budowa geologiczna (in Polish). In: Objaśnienia do mapy geośrodowiskowej Polski 1:50 000 Arkusze Międzywodzie (75) i Wolin (114) (eds. Z. Beedkowski, K. Siwy-Będkowska, A. Wąsowicz, J. Król, A. Pasieczna, P. Kwecko, I. Bojakowska and H. Tomassi-Morawiec): 8-13. Państwowy Instytut Geologiczny - Państwowy Instytut Badawczy, Warszawa.

Šimkevičius, P., 1998. Jurassic of the South-Eastern Baltic: Lithology and Clay Minerals. Vilnius.

Van Loon, A.J. (Tom), Pisarska-Jamroży, M., 2016. Changes in the heavy-mineral spectra on their way from various sources to joint sinks - a case study of Pleistocene sandurs and an ice-marginal valley in NW Poland. In: Sediment Provenance: Influences on Compositional Change from Source to Sink (ed. R. Mazumder): 49-62. Elsevier.

van Wees, J.-D., Stephenson, R.A., Ziegler, P.A., Bayer, U., Mc-Cann, T., Dadlez, R., Gaupp, R., Narkiewicz, M., Bitzer, F., Scheck, M., 2000. On the origin of the Southern Permian Basin, Central Europe. Marine and Petroleum Geology, 17: 43-59.

Vareikienè, O., Marmo, J., Chernet, T., Laukkanen, J., 2007. Results of heavy mineral pre-concentration by the Knelson for the geochemical study of soil: a case study in Lithuania. Geologija, 60: $1-9$

Wajda, W., 1970. Heavy minerals of the bottom sand (Polish Coast) Baltic (in Polish with English summary). Annales de la Société Géologique de Pologne, 40: 131-149.

Weibel, R., 1998. Diagenesis in oxidising and locally reducing conditions - an example from the Triassic Skagerrak Formation, Denmark. Sedimentary Geology, 121: 259-276.

Weibel, R., Friis, H., 2004. Opaque minerals as keys for distinguishing oxidising and reducing diagenetic conditions in the Lower Triassic Bunter Sandstone, North German Basin. Sedimentary Geology, 169: 129-149.

Weibel, R., Friis, H., 2007. Alteration of opaque heavy minerals as a reflection of the geochemical conditions in depositional and diagenetic environments. Developments in Sedimentology, 58: 277-303.

Weltje, G.J., von Eynatten, H., 2004. Quantitative provenance analysis of sediments: review and outlook. Sedimentary Geology, 171: 1-11.

White, W.A., 1972. Deep erosion by continental ice sheets. GSA Bulletin, 81: 1037-1056.

Woronko, B., Rychel, J., Karasiewicz, M.T., Ber, A., Krzywicki, T., Marks, L., Pochocka-Szwarc, K., 2013. Heavy and light minerals as a tool for reconstructing depositional environments: an example from the Jałówka site (northern Podlasie region, NE Poland). Geologos, 19: 47-66.

Ziegler, P.A., 1978. North-Western Europe: tectonics and basin development. Geologie en Mijnbouw, 57: 589-626.

Ziegler, P.A., 1990. Geological Atlas of Western and Central Europe. 2nd Edition, Shell Internationale Petroleum Maatschappij BV, Geological Society of London. Elsevier, Amsterdam.

Żelaźniewicz, A., Aleksandrowski, P., Buła, Z., Karnkowski, P.H., Konon, A., Oszczypko, N., Ślączka, A., Żaba, J., Żytko, K., 2011. Regionalizacja tektoniczna Polski (in Polish). Komitet Nauk Geologicznych PAN: 7-14.

Żywiecki, M., Ceranka, T., Joachmiski, M., 2010. Analiza izotopowa (in Polish). In: Dokumentacja geologiczna otworu badawczego Rzeczyn PIG-1 (eds. B.A. Matyja, M. Barski, T., Ceranka, R. Dobrecki, J. Dzierżek, M. Jackiewicz, O. Rosowiecka and M. Żywiecki): 151-165. Państwowy Instytut Geologiczny. 